\title{
CHANGING PORTRAYALS OF CAPTAIN JAMES COOK IN HAWAIIAN EDUCATION
}

\author{
A Thesis \\ presented to \\ the Faculty of California Polytechnic State University \\ San Luis Obispo
}

In Partial Fulfillment

of the Requirements for the Degree

Master of Arts in History

by

Christopher Aaron Straub

November 2009 
(C) 2009

Christopher Aaron Straub

ALL RIGHTS RESERVED 


\section{COMMITTEE MEMBERSHIP}

\section{TITLE: $\quad$ CHANGING PORTRAYALS OF CAPTAIN JAMES COOK IN HAWAIIAN EDUCATION}
AUTHOR:
Christopher Aaron Straub
DATE SUBMITTED: November 2009

COMMITTEE CHAIR: $\quad$ Dr. Tom Trice, Director, M. A. Program

COMMITTEE MEMBER: Dr. Daniel E. Krieger, Professor of History Emeritus

COMMITTEE MEMBER: $\quad$ Dr. Detweiler, Trustee Professor 


\section{ABSTRACT \\ CHANGING PORTRAYALS OF CAPTAIN JAMES COOK IN HAWAIIAN EDUCATION}

\section{Christopher Aaron Straub}

This paper covers the portrayals of Captain James Cook within Hawaiian education. It begins by providing a backdrop to early European portrayals of Captain Cook and then proceeds to investigate how these portrayals changed as they were incorporated into Hawaiian textbooks. The paper then continues to illustrate the changes made in Cook's portrayal within Hawaiian textbooks and how these changes coincide with the prevailing interests of the eras in which the authors wrote them.

Keywords: Captain Cook, Hawaii, Education, Textbooks. 


\section{ACKNOWLEDGEMENTS}

This paper has been one of the most difficult projects of my life and I would like to thank Dr. Trice, Dr. Detweiler, and Dr. Krieger for assisting me in preparing it for fruition. I would also like to thank Dr. Murphy for encouraging my interest in maritime history. Thank you also to all my colleagues who are on the same path and endure many of the same obstacles. Together we prevail. 


\section{TABLE OF CONTENTS}

CHAPTER Page

I. INTRODUCTION 1

II. Captain Cook's Three World Voyages and Their Accounts 6

Early Biographical Works on Cook 11

The "Heroizing" of Captain Cook 12

Education in Hawaii $\quad 15$

II. Hawaiian History Textbooks 21

$\begin{array}{ll}\text { Missionary Era Texts } & 21\end{array}$

Transition from the Missionary Era to the Plantation Era 26

$\begin{array}{ll}\text { Plantation Era Texts } & 34\end{array}$

The Tourism Era 41

$\begin{array}{ll}\text { Tourist Era Textbooks } & 50\end{array}$

Native Hawaiian Movement Era and Textbooks Today 58

III Summary and Conclusion $\quad 68$

$\begin{array}{ll}\text { BIBLIOGRAPHY } & 72\end{array}$ 
Captain James Cook's third and final world voyage in 1776 brought a wealth of controversial issues to the world of history. His legacy as a British seaman and explorer has filled volumes. Cook's "discovery" of the Hawaiian Islands and the consequences that followed remain a viable topic over two hundred years later.

Hawaiians learn about Captain Cook in school textbooks as part of their social studies curriculum. Cook's encounter with the Hawaiians marked a turning point in history. Editors, biographers, missionaries, and historians, including authors of Hawaiian textbooks, have accounted for this important event in numerous ways. One of these textbooks states that:

Captain Cook kept a careful record of his voyages. He wrote an exciting story that told about the welcome given to him. 'Natives came out in their canoes to meet us. They seemed very happy we had come. We were surprised to find that they spoke about the same language as that of Otahiti (Tahiti) where we had visited. ${ }^{1}$

This passage is from a contemporary textbook used in many seventh-grade Hawaiian classrooms. The first two lines of the passage raise questions about the nature of sea voyage narratives. Where did they come from? Did Cook really write them? How have they been influenced over the past two centuries? The quotation within the passage is allegedly from Cook, and it also offers insight into how he may have chosen to convey his experience. In essence this is the first documented convergence of the Hawaiian culture with a European one, and this in itself brings forth a debate. ${ }^{2}$ The report here is from the perspective of a European, possibly Cook. His description portrays a benevolent meeting between the two cultures. Was this really the case? What was the Hawaiians'

\footnotetext{
${ }^{1}$ Helen Bauer, Hawaii: The Aloha State (Garden City, NY: Doubleday and Company, 1960), 46.

${ }^{2}$ A debate over whether or not Cook was the first European to discover Hawaii began with a few of the early accounts on Hawaiian History. For more information see: E.W. Dahlgren's 1916 publication The Discovery of the Hawaiian Islands.
} 
point of view? The final sentence in the passage that connects Hawaii to Polynesia also alludes to the bigger picture of what was going on in both Europe and Hawaii at the time of Cook's arrival. Why was Cook in the area of Hawaii? What was Hawaii like at this time? What reasons have been given to explain the treatment of Cook by the Hawaiians, and vice versa?

If these questions can be raised from such a brief passage, what else can be gleaned from other portrayals of Cook's encounter with Hawaiians within similar texts? The purpose of this paper is to provide a thorough investigation into how Cook's story in Hawaii has been handled over the past two centuries. More specifically, it will look at how this story has been used in educating generations of Hawaiians about Cook. Therefore, this investigation will focus on textbooks that have been used in Hawaii as both aids to teachers as well as for students in the classroom. The portrayals of Cook change over time and reveal a great deal about Hawaii's relationship to the world.

I have found that the way Cook is presented in Hawaiian textbooks has changed in reflection of changes in how Hawaii history itself has been written and re-written through changing eras. Thus, the way that Cook is treated reflects the predominant views and biases of the following eras: “missionary" (1820's - 1880's), “plantation” (1880's 1950's), “tourism" (1930's - present), and “native Hawaiian movement" (1960's present). Portrayals of Cook were skewed to reflect the bias of these different eras, and these portrayals were not always historically accurate.

After providing a brief account of Cook's early background, I will first examine accounts written during Cook's tenure as an explorer, then how early biographers handled these journals. Following Cook's death, works began to create a hero of the 
British sea captain; I will briefly describe this heroizing process before shifting to an overview of education in Hawaii. Once a backdrop has been given on early works on Cook and education in Hawaii, I will begin a chronological examination of educational works used on the Hawaiian Islands during the missionary, plantation, tourism, and native Hawaiian movement periods. Within these works I will focus on: the context of the account (whether it is from a European, American, or Hawaiian point of view); trade and transactions between the Hawaiians and British (including the violence that resulted from cultural misunderstanding); Cook's deification by the Hawaiians and the reasons for it; and how and why Cook died.

The historiography that accompanies this era of explorations and one of its lead characters is expansive, as over four thousand books have been written on Captain Cook. ${ }^{3}$ Historical inaccuracies began distorting Cook's portrayal with the first publication of his journals edited by John Hawkesworth. It improved immediately thereafter, at least in Cook's mind, but again not without faults. Many of Cook's contemporaries reveal parallel positive portrayals of Cook; some however paint Cook in an alternate fashion. Early biographical works, such as the one written by author Andrew Kippis in 1788, upheld a positive Eurocentric view of Cook. ${ }^{4}$ Later, classic works produced by author and editor John C. Beaglehole arguably served to maintain a more well balanced approach to Cook's life and work. However, many scholars looking to find new ground on the subject of Cook often contest Beaglehole's work as well. Recent works such as Glyndwr

\footnotetext{
${ }^{3}$ Greg Dening, "Reviews of Books," review of Captain James Cook by Richard Hough, The Apotheosis of Captain Cook: European Mythmaking in the Pacific by Gananath Obeyesekere, How "Natives" Think: About Captain Cook, For Example by Marshall David Sahlins, The William and Mary Quarterly 54, no. 1 (January 1997): 253. (JSTOR).

${ }^{4}$ This view upholds the belief that European culture(s) are superior to others, such as, in this case, Pacific Islanders.
} 
Williams's The Death of Captain Cook: A Hero Made and Unmade, as well as classic works by art historian Bernard Smith have offered insight into the myth-making of Captain Cook's character. ${ }^{5}$

Hawaii has a rich history of its own that stretches back a millennium to when the Polynesians migrated throughout the Pacific. There are Hawaiian accounts of foreigners visiting the islands even before Cook, but no one knows their level of validity. ${ }^{6}$ At the time of Cook's arrival the Hawaiian Islands were divided by chiefdoms existing on each main island with approximately a million people living throughout the islands. With such a large population, it may not be surprising that there was inter-island conflict prior to Cook's arrival. Once Cook and his crew landed, their meeting with the Hawaiians was truly a change worthy event that altered both relations between the East and West.

Although native Hawaiian views of Cook have undoubtedly existed since his arrival, the past two decades have brought these alternative viewpoints from both 'foreign' and 'native' voices. Although heavily influenced by missionary theology, early works by native Hawaiian historians S.M. Kamakau and David Malo set the stage for the Hawaiian perspective of Cook. More recently, native voices such as Julie Kaomea's provide fresh wisdom into Cook's portrayal. She argues in her article, "A Curriculum of Aloha? Colonialism and Tourism in Hawaii's Elementary Textbooks," that Cook propagated a portrait of subservient Hawaiians that blossomed into today's tourist

\footnotetext{
${ }^{5}$ John Hawkesworth, An Account of a Voyage Round the World with a Full Account of the Voyage of the Endeavor in the Year MDCCLXX Along the East Coast of Australia (Brisbane: Smith \&Paterson, 1969); Andrew Kippis, The Life of Captain James Cook (London: Printed for G. Nicol and G.G. J and J Robinson, 1788); John C. Beaglehole, The Life of Captain James Cook (Stanford: Stanford University Press, 1974); John C. Beaglehole, The Journals of Captain James Cook (New York: Penguin Books, 1999); Glyndwr Williams, The Death of Captain Cook: A Hero Made and Unmade (Cambridge: Harvard University Press, 2008); Bernard Smith, European Vision and the South Pacific (New Haven: Yale University Press, 1985). ${ }^{6}$ A discussion of this can be found in E.W. Dahlgren's 1916 publication The Discovery of the Hawaiian Islands.
} 
industry mentality of "Aloha" through Hawaiian textbooks. Other works by anthropologists Marshall Sahlins and Gananath Obeyesekere have clashed to create a debate over portrayals of Cook immediately before, during, and after his death. ${ }^{7}$

Most Hawaiian social studies students are at the mercy of teachers and textbooks that have a condensed and often skewed version of Cook's history in Hawaii. They do not reflect the rich detail of portrayals in more sophisticated historical studies. In the past, many of these schools in Hawaii have operated on short funding and are often forced to use old and outdated textbooks. This situation has been improving and positive changes are being made. Continuing on the right path is now the concern for historians and educators. $^{8}$

Cook is introduced to Hawaiian students at least three different times in their educational upbringing. Generally students begin learning about Cook within the framework of the Hawaiian culture and history curriculum in the fourth grade. Then, in the seventh grade they are taught about foreigners and missionaries. Finally, in either the $9^{\text {th }}$ or $11^{\text {th }}$ grade they are taught about Cook through the history of Hawaiian economics. ${ }^{9}$ Education at these grade levels allows for the portrayal of Cook to grow and expand into various forms. It is the intent of this paper to show how these forms developed and how they are directed.

\footnotetext{
${ }^{7}$ Samuel Manaiakalani Kamakua, Ruling Chiefs (Honolulu: Kamehameha Schools Press, 1961); David Malo, Hawaiian Antiquities (Moololo Hawaii) (Honolulu: Bernice P. Bishop Museum, 1951); Julie Kaomea, "A Curriculum of Aloha? Colonialism and Tourism in Hawaii's Elementary Textbooks," Curriculum Inquiry 30, no. 3 (Autumn, 2000): 319 - 344. (JSTOR); Marshall Sahlins, How "Natives" Think: About Captain Cook, For Example (Chicago: University of Chicago Press, 1995); Gananath Obeyesekere, The Apotheosis of Captain Cook: European Mythmaking in the Pacific (Princeton: Princeton University Press, 1997).

${ }^{8}$ Benjamin Bess, e-mail message to author, Januuary $26^{\text {th }}, 2009$. Benjamin Bess is the publisher of Bess Press in Hawaii.

${ }^{9}$ Hawaii Department of Education, "Hawaii Content and Performance Standards III Database," http://standardstoolkit.k12.hi.us/index.html (accessed November 20, 2008).
} 


\section{Captain Cook's Three World Voyages and Their Accounts}

Even before the missionary period $(1820$ - 1880's) there were shifting perspectives of Cook's voyages. His first world voyage in 1768 was a scientific expedition to the island of Tahiti to record the transit of Venus across the sun. ${ }^{10}$ Under the auspices of both the Royal Navy and Britain's Royal Society, Cook's journey was intended to benefit the ongoing task of improving the ability to read longitude. ${ }^{11}$ However, the primary astrological goal of recording the transit of Venus provided little help in accomplishing this task. However, Cook proved his usefulness as he sailed on. He managed to accurately map all of New Zealand, and from there he made his way to what is now Australia. This discovery was somewhat more significant and marked the first European contact with indigenous Australians. ${ }^{12}$ Encounters with unfamiliar cultures such as this provided entertaining material to the masses back home, and thereby garnered support for imperial exploration and expansion.

Understanding the popularity and importance of sea voyage narratives in Cook's time is essential to all that follows in the historical account of Cook in Hawaii. Sea voyage narratives were a primary source of entertainment throughout the eighteenth century. They also educated the public about the world around them, but many times this education was tainted by the precedence of a writer's task of spinning a good story. Most of what was written by Cook, and the men that sailed with him, was for the use of the Royal Society. However, this is not to say that stories were not profitable, they were, and

\footnotetext{
${ }^{10}$ Robin Fisher and Hugh Johnston, Captain James Cook and His Times (Seattle: University of Washington Press, 1979), 50. The Royal Navy and the Royal Society became involved in a power struggle to control such expeditions.

${ }^{11}$ Derek Howse, Background to Discovery: Pacific Exploration from Dampier to Cook (Berkeley: University of California Press, 1990), 174.

${ }^{12}$ John Cawte Beaglehole, The Life of Captain James Cook (Stanford: Stanford University Press, 1974), 229. Cook did not discover Australia; he was just the first to encounter the aborigines along the east coast.
} 
this naturally was factored into a journal keeper's practice. Most seamen were not the best of writers, and in order for their stories to be released to the public they often had to be edited.

After Cook's first journey, the journals of Joseph Banks, Cook and others were handed over to Dr. Hawkesworth, a professional writer with absolutely no sea experience. ${ }^{13}$ The decision to commission Hawkesworth to edit the journals of the Endeavor was made by Lord Sandwich, First Lord of the Admiralty. ${ }^{14}$ The publication sold well but was harshly critiqued for a variety of reasons, including misrepresentation of facts. Hawkesworth managed to blend Cook's and Bank's accounts with his own morally tinged spin. ${ }^{15}$ Hawkesworth prejudged primitive societies without even seeing them. He also attempted to explain Cook's reasoning, especially in regards to handling natives. Hawkesworth was simply careless in such efforts, portraying both Cook and natives poorly. In addition, Hawkesworth ignored and refused corrections suggested by Cook. $^{16}$

The influence of Hawkesworth's Account of the Voyages, and the fact that it was not withdrawn or replaced for a hundred years, did irreparable damage to Britain. ${ }^{17}$ Cook's personal involvement with Pacific natives and the relationship he had with them

\footnotetext{
${ }^{13}$ Joseph Banks was a budding naturalist and social elitist who had joined Cook on the Endeavor as part of the group of scientists under the auspices of the Royal Society. He was also socially superior to Cook at the time.

${ }^{14}$ Philip Edwards, The Story of the Voyage: Sea Narratives in Eighteenth-Century England (Cambridge: Cambridge University Press, 2004), 83-84.

${ }^{15}$ Joseph Banks managed to influence Hawkesworth, promoting his character, often at the expense of Cook's. It is important to note that Banks was better seasoned as a public figure than Cook, who was only a lieutenant at the time.

${ }^{16}$ W. H. Pearson, "Hawkesworth's Alterations," The Journal of Pacific History 7 (1972): 57. (JSTOR).

${ }^{17}$ Edwards, 92.
} 
is still being reconstructed today. ${ }^{18}$ Unfortunately, many of Hawkesworth's "liberties' make it difficult to understand Cook today.

Cook's second world voyage from 1772 to 1775 concentrated on southern exploration, specifically the discovery of an alleged southern continent. ${ }^{19}$ He returned to the Pacific, sailing around the coastline of Antarctica. These travels included stops to recently explored destinations such as New Zealand and Tahiti, but also new discoveries within the Taumoutu Islands, Society Islands, Tonga and Fiji Islands. Other notable stops were the Marquesas Islands, Easter Island, and New Caledonia. Cook returned with confidence that no southern continent existed. ${ }^{20}$

John Douglas, canon of Windsor, edited the journals of Cook's second expedition. After learning how upset Cook was with Hawkesworth's fouling of the Endeavor's journals, Douglas maintained extreme care when editing Cook's southern exploration journal. It has been argued that Douglas made a few crucial deletions, but for the most part the published product is often regarded as Cook's only complete publication. ${ }^{21}$

Despite the improvement of an editor, the account of Cook's second voyage did not go without incident. John Forster, a botanical collector, and his son George Forster, an artist, competed with Cook to release the official account of the journey. Both Cook and Forster believed they should be responsible for the official history of the voyage. Cook was upset by Hawkesworth's rendition of his first voyage and wanted to redeem himself. However, Forster allegedly had a legal agreement with the admiralty to publish

\footnotetext{
${ }^{18}$ Edwards, 89.

${ }^{19}$ Edwards, 82. At the time it was believed that a Southern Continent existed at lower latitudes.

${ }^{20}$ Beaglehole, The Life of Captain James Cook, 366.

${ }^{21}$ Edwards, 118, 123.
} 
the account. Once the Resolution docked it became a "violent controversy." 22 A final decision was made to use Cook's narrative unless Forster made changes to appease the admiralty. ${ }^{23}$ Forster would not agree. Surprisingly, his son George Forster, who was also aboard, took upon the exhausting task of reworking everything his father had written and published six weeks before Cook's version made it to print. Examples such as this convey the importance of sea-narratives, not only as a source of financial gain, but also as a means of accurately upholding one's reputation. ${ }^{24}$

Cook was again enticed to sail by the Royal Society shortly after returning from his second voyage. The main objective of Captain Cook's third voyage was to investigate whether or not a passage linked the northern Atlantic Ocean to the Pacific Ocean. In early July of 1776, Cook sailed from Plymouth, England, approximately a week after America had declared its independence from England. As a measure of safety, a common agreement was made that neutrality be taken toward Cook's ships. ${ }^{25}$

Cook and his crew stopped at several islands in the Pacific before making their way to look for the Northern Passage. Cook was also returning Omai, a native to the Society Islands who had been taken back to England during his previous voyage. Interludes before returning Omai to his land of birth refamiliarized Cook and his men with the incessant tendency of stealing by many throughout the Pacific. This exacerbated trait challenged Cook and his men throughout the remainder of their journeys.

Upon leaving Tahiti, Cook and his men set out on their way to look for the Northern Passage. Sailing northward, Cook spotted two islands that belonged to a chain

\footnotetext{
${ }^{22}$ Edwards, 112.

${ }^{23}$ Edwards, 114. These changes were requested due to John Forster's over-sentimentality.

${ }^{24}$ Edwards, 108-113.

${ }^{25}$ Christopher Lloyd, The Voyages of Captain James Cook: Round the World (London: The Cresset Press, 1949), 252n.
} 
they subsequently called the Sandwich Islands, after Cook's friend and Lord of the Admiralty. Today, they are known as the Hawaiian Islands.

Captain Cook's time in Hawaii totaled approximately four months. His first visit, in January of 1778 , lasted about a month. Cook and his men traded for supplies, supplying themselves with enough provisions to proceed with their mission. He accounted for sighting five islands (Oahu, Kaua'i, Ni'ihau, Molokai, Lanai), and learned that there were perhaps more. His first attempt at the Northern Passage ended in retreat from an arctic storm; he returned to the Hawaiian Islands in late November of 1778. For obscure reasons, Cook made a decision to remain unanchored as he tacked around the island of Maui for nearly two months. Again during this time he traded with natives and had transactions with a few of the island's chiefs. Perhaps it was at this point that Cook might have learned about the inter-island wars occurring at the time. In January, he circled around the large island of Hawaii and anchored in Kealakekua Bay, where he remained anchored for almost a month. On February 11th, with another full stock of supplies, Cook once again ventured out to make another run at the Northern Passage. Unfavorable weather thwarted this departure as well, and Cook and his men turned back. Finding no other acceptable harbor, they returned to Kealakekua Bay. Two days later on February 14th, while attempting to take the king of the large island hostage as a way to recover the theft of a cutter, a quarrel between the Hawaiians and British began and Cook was stabbed in the back and died. His crew departed from Kauai on February 22nd. ${ }^{26}$

\footnotetext{
${ }^{26}$ This description gives only the generalist overview of time, place, and basic activity. It should also be noted that the official account of Captain Cook's third voyage was a compilation effort by Captain Cook, Captain King, and editor John Douglas. Other works have gleaned information from the journals and accounts by Ledyard, Ellis, Samwell, and Zimmerman, members of Cook's crew.
} 


\section{Early Biographical Works on Cook}

The mid-twentieth century brought a new scholar to those intrigued by Captain Cook, John C. Beaglehole. A New Zealand writer and historian, Beaglehole dedicated a lifetime of research to Captain Cook. During this span he wrote an article that highlighted many of the biographers of Cook, and thereby provided a historiographic glimpse into the subject of Cook. I have chosen to include descriptions of two early biographers of Cook, Andrew Kippis and Arthur Kitson, whose writings stood as the authoritative works on Cook before Beaglehole himself trumped them.

Kippis wrote the first biographical piece on Captain Cook. Beaglehole explains that this work served as the standard life of Cook for one hundred and nineteen years. As Beaglehole points out, Kippis's biography was nothing more than a reduction of the seven volumes of the officially published Voyages, written by Captain Cook, Captain King, and editor John Douglas. More financially driven as a professional biographer, Beaglehole explains that Kippis had no deep personal interest in Cook. He gives notes that Kippis missed the opportunity to investigate where Cook grew up - passing over interviews of the people that had met and worked with Cook. Despite Beaglehole's frustration with Kippis, he gives credit where it is due and applauds him for being the one who revealed how Cook was "trapped into volunteering for the third voyage."27 Beaglehole later built an argument from this claim by Kippis and asserted that Cook was "tired" on his third and final voyage, and thereby made more pronounced errors in judgment. According to Beaglehole, this mental and physical exhaustion, with little rest in between each of Cook's world voyages, contributed to Cook's demise.

\footnotetext{
${ }^{27}$ John Cawte Beaglehole, “Some Problems of Cook's Biographer," Mariner's Mirror 55, no. 4 (1969): 368. Many other biographers wrote on Cook, but for the purpose of this paper these are the most important ones.
} 
In 1907, businessman Arthur Kitson was the next biographer to gain a following. Beaglehole explains that Kitson was thorough in scouring the Public Record Office, and debunked parts of Kippis's work. Kitson's contribution came through his high personal interest in Cook. He consulted experts and utilized correspondence letters to provide a closer glimpse inside of Cook's life. Kitson's work became a cornerstone for future biographers to build from. ${ }^{28}$

\section{The "Heroizing" of Captain Cook}

Even before Cook's first voyage he was well respected in his field. Lord Colville, a superior officer to Cook, described him as "a man of 'genius and capacity." ${ }^{, 29}$ Of course there was an exception or two, but overall Cook's contemporaries thought and spoke highly of him. However, earning the respect of his comrades and other accredited men was just the beginning of Cook's exalted reputation.

England's recent loss of America created the dire need for a hero, and thus some of the most significant sources in perpetuating the portrayal of Captain Cook arrived shortly after his death. Bernard Smith, an art historian writing in the nineteen sixties, analyzed the eulogies and artwork depicting Captain Cook that are still used, directly and indirectly, to portray Cook today. He divided the 'intention' of artists in two, explaining that some aimed to accurately portray Cook's life and death, while others "concerned themselves with celebrating his life while using it, even if unwittingly, to support their own interests and concerns. ${ }^{30}$ However, Smith recognized that such a division is not

\footnotetext{
${ }^{28}$ Beaglehole, "Some Problems of Cook's Biographer," 369.

${ }^{29}$ Bernard Smith, "Cook's Posthumous Reputation," in Captain James Cook and His Times, ed. Robin Fisher and Hugh Johnston (Seattle: University of Washington Press, 1979), 159.

${ }^{30}$ Smith, 160 .
} 
realistic, as he showed that even the "most meticulous of Cook scholars," such as J.C.

Beaglehole, glorified Cook by describing him as "our Hero" on several occasions. ${ }^{31}$

Indeed, Beaglehole would come to be viewed as an overly favorable critic who

overlooked certain flaws of Cook.

In order to provide a better understanding, Smith placed the admiration to follow

Cook's death in context. This was the era of imperial expansion, and Cook's efforts to

explore regions unknown earned him a place at the top of this moment in history. Smith

writes:

After his death, Cook's life and achievements provided the material from which a new kind of hero, one admirably adapted to the needs of the new industrial society of Europe in its global expansion, was fashioned. Cook became the first and most enduring hero of European expansion in the Pacific; or to put it bluntly, the protypical hero of European imperialism. ${ }^{32}$

Nearly all men, from the common seaman to socialites such as Sir Joseph Banks and George Forster, men who were well aware of Cook's faults, "cherished" his memory. ${ }^{33}$

Despite Cook's own wishes to be considered merely a serviceman, eulogies from around Europe began "heroizing" him. ${ }^{34}$ All sorts, from near and far, remarked upon his death. Descriptions included the points that Cook was a self-made man, a great figure of the Enlightenment and a patriotic hero. Smith remarks that these eulogies brought forth the notion that, "Cook is praised because he brought the agricultural arts of his country, instead of the roar of the cannon, to the Pacific." ${ }^{35}$ An important point to note is that a

\footnotetext{
${ }^{31}$ Smith, 160.

${ }^{32}$ Smith, 160.

${ }^{33}$ Smith, 160. This is not the case across the board while he was alive; he had a few foe like characters in his life, but still a rather mild show of them.

${ }^{34}$ Smith, 161.

${ }^{35}$ Smith, 162, This statement continues in explanation, that Cook of course brought both animals and cannons, but that the heroizing process relishes in the nature of his journeys and forgives the one for the other.
} 
main characteristic of many of these eulogies was a blending of old and new manners of heroizing. References to Classical (Greek and Roman) and Biblical pieces tied Cook into something greater than his own time, something immortal. Thus, Cook's character began to be uplifted, and he eventually became a symbol of the Enlightenment.

Visual arts propelled the heroizing of Cook even further. Smith analyzed the various works on Cook by showing the influential nature of the visual accounts of Cook. Two original pieces served as the foundation to Cook's pictorial martyrdom that expanded through the ages, with only one of the artists having been a member of Cook's crew. John Webber was the artist aboard Cook's ship during his third voyage. He most likely did not witness Cook's death, but was certainly influenced by the information that traveled back to the Resolution and from Captain James King's later account. Smith described Webber's work as follows:

...the two boats offshore, with the marines firing from the distant, a couple struggling in the water to gain the boats; Lieutenant Phillips, fallen to the ground, firing at his assailant; Cook about to be stabbed in the back by a huge native as he turns and gestures towards the launch. ${ }^{36}$

Smith ponders over the hand gesture in the painting and its significance. He asserts that this gesture is "key to the emotional tone of the painting, and is enigmatic." Ambiguity arises over whether or not Cook is waving to Lieutenant Williamson to stop firing and pull into the shore to help him escape, or more exclusively to stop firing at the natives. ${ }^{37}$ The latter scenario, being an act of complete humanitarianism and martyrdom, would have said something larger about Cook. Could this have been true? There's evidence within the accounts on Cook to argue both ways.

\footnotetext{
${ }^{36}$ Smith, 169.

${ }^{37}$ Smith, 169.
} 
The second most influential painting is a product of John Cleveley. His brother James was the carpenter onboard the Resolution, and created a drawing that is allegedly the inspiration for John's piece. Smith notes that Cleveley uses the same enigmatic hand gesture as Webber, and in addition he adds a puff of smoke, appearing from musket fire, which creates a halo around Cook. ${ }^{38}$ Smith explains that the paintings of Webber and Cleveley's are most widely used, and not necessarily for their historical accuracy. In fact, others produced after theirs may have been more historically accurate, due to the synthesis of information available years later. Webber and Cleveley's value in spawning a surplus of mimicry works was the fact that they portrayed Cook in a heroic tone. With its recent failure in America, England needed a world hero to give its imperial expansion purpose and uplift its public morale. Both Cleveley's and Webber's work contributed to that need.

Cook's portrayal as a heroic explorer soon changed over time. Other influential works began to form their own versions of Cook. Both positive and negative interpretations have left the real Captain Cook to remain elusive. The Hawaiians, perhaps above all else, have vacillated in their opinion on Cook. Changes in the Hawaiian education system help explain these vacillations.

\section{Education in Hawaii}

Hawaiian education has gone through several drastic changes over the past two centuries, and the shifting perspectives of Cook tend to follow these changes. Beginning with a major shift from a traditional oral-style, community driven, education, to a tightly knit religious based approach imposed by missionaries, Hawaiians learned the ways of

\footnotetext{
${ }^{38}$ Smith, 169.
} 
the literate Christian world. During both the plantation and tourism eras in Hawaii, an American driven educational system has gradually become implemented in their society.

Education in Hawaii prior to Captain Cook's landing was a highly collaborative, but informal experience. Twenty or more family members, spanning three or four generations, participated in a child's upbringing. Counter to social protective methods developed in Anglo-Saxon cultures, secrecy of speech and action were rarely practiced in Hawaiian society. Gender roles were crossed, as "Much [of] a child's education consisted of observing family members in their daily activities and eventually trying the tasks themselves." ${ }^{39}$ Regulating behavior was achieved by the kapu system, based on restriction and allowance of action. With priests placing a taboo on certain activities, order was kept. For example, when Cook and his men arrived in the bay at Kealakekua a taboo was set on the bay that forbid traveling into it. This was very likely a way of regulating action during a king's absence and protecting people from invaders from other islands; for if a taboo was set on entering the bay, then anyone who entered the bay must surely be viewed as a warring party. Magnificent to the Hawaiians, Cook and his crew were obviously an exception. However, priests most likely still had to give their allowance before anyone entered the bay to greet Cook and his men.

Following Captain Cook's arrival, Hawaii's relationship with foreigners, especially America, continued to develop. In 1820, President Monroe sent John Coffin Jones to Hawaii as the first agent to represent a foreign government. This was the first time that Hawaii's government dealt with foreign powers on official relations with any

\footnotetext{
${ }^{39}$ Marion Kelly, "Some Thoughts on Education in Traditional Hawaiian Society," in To Teach the Children: Historical Aspects of Education in Hawaii. A Publication Accompanying the Exhibition Commemorating the 50th Anniversary of the College of Education and the 75th Anniversary of the University of Hawaii (Honolulu: Bernice Paul Bishop Museum, 1982), 4.
} 
country other than England. Complex trade relations throughout the Pacific in fur, sandalwood, and whaling led Hawaii to sign a treaty with America ensuring peace and friendship between the two countries. This agreement protected American trade and thereby allowed for America to gradually supplant England's hold on the territory. ${ }^{40}$

Hawaiian education also went through several major transitions. In October of 1819, the American Board of Commissioners for Foreign Missions sent New England Protestant missionaries to Hawaii. ${ }^{41}$ These missionaries were referred to as the "First Company" and were led by Reverend Hiram Bingham and Reverend Asa Thurston. Bingham and Thurston, aided by other educators and interpreters trained in Cornwall, Connecticut, dispersed themselves about the islands. ${ }^{42}$ Teaching the Christian religion was their main objective, but as they aimed to reproduce the Bible in the Hawaiian language they also managed to produce a work on the history of Hawaii. Sheldon Dibble, a lead missionary, helped create the first text written about Hawaiian history that included the story of Captain Cook's arrival.

Formalized education continued as American influence blossomed over the next century. Beginning in the 1820's, American missionaries settled children, as well as adults, into a more structured classroom setting. During the 1840's, Hawaiian historian David Malo became the first government superintendent of education. He participated in shaping the monarchy's role in education. Following Malo, Reverend Richard Armstrong became the superintendent from 1848 to 1860 , and developed the school system further

\footnotetext{
${ }^{40}$ Ralph Kuykendall, A History of Hawaii (New York: McMillan Company, 1933), 118, 124, 126.

${ }^{41}$ Approximately a year later in 1820, president Monroe sent John Coffin Jones to Hawaii as the first foreign agent

${ }^{42}$ Arthur Grove Day, Hawaii and Its People (New York: Meredith Press, 1968), 76-77.
} 
by codifying school laws and procedures. Armstrong also gradually shifted away from denominational schooling in favor of a nonsectarian approach. ${ }^{43}$

Hawaii is commonly referred to as the "crossroads to the Pacific." This is because many ethnic groups have poured into Hawaii over the past two centuries. With fur traders, whalers, missionaries, merchants, and others settling in the islands, Hawaii's population diversified. Social changes were primarily steered by American missionaries and foreign enterprises. ${ }^{44}$ These white elites shaped public schooling for indigenous Hawaiians, Chinese, Japanese, Filipino, and other immigrants.

Americanization, or the acculturation of Hawaiians into American traditions and ideals, began with the missionaries and then flourished as America took more interest in the Islands. ${ }^{45}$ Because English was the predominant language in trade, many Hawaiians began requesting that English be used in the classroom in place of Hawaiian. Originally this shift in language priority began under private schools for those able to afford it. ${ }^{46}$ This started a divide in education that fed into the social stratification process. However, "A decade before annexation [in 1898], a steady advance was begun toward achieving the American ideal of universal, compulsory, nonsectarian, and tax-supported education."47 Although private schools would continue to excel in Hawaii, the act of prioritizing English in the classroom eventually furthered the Americanization process throughout Hawaii.

\footnotetext{
${ }^{43}$ Day, 195. By 1853 , government common schools no longer had sectarian headings.

${ }^{44}$ Kelly, 22.

${ }^{45}$ Roger J. Bell, Last Among Equals: Hawaiian Statehood and American Politics (Honolulu: University of Hawaii Press, 1984), 93.

${ }^{46}$ Kelly, 23.

${ }^{47}$ Day, 238.
} 
Labor recruitment policies of the plantations brought another side of the diversity to Hawaii, as many Asians were hired as plantation workers. This created an obstacle to the Americanization process that was well underway. For example, the Japanese never believing it the American right to rule Hawaii set up Japanese language schools to solidify their culture in Hawaii. The result of this diversity convoluted the educational process further by inhibiting synchronicity between ethnic groups. However, this would soon change.

America's annexation of the Hawaiian Islands in 1898 further instilled the Americanization process. A claim that American institutions, such as schools, were already in place created a reason for America's presence; it then became the improvement of those institutions that was needed in order to move Hawaii into the future. With an increasing need for solidarity, a federal survey was conducted in 1919. The survey led to more concrete Americanization, but not without hurdles. ${ }^{48}$ There were only four public high schools in 1920. This was largely due to the plantation ideology that nothing beyond primary education was necessary for workers destined to a life in the fields. ${ }^{49}$ Nevertheless, an expansion of secondary schools was implemented slowly throughout the islands.

Other changes contributed to Hawaii's educational transformation. The governor during Hawaii's period of annexation, Wallace R. Farrington, worked with superintendents to transform Hawaiian schools even more. During the 1920's secondary schools implemented vocational training into their curriculum. This progressive move

\footnotetext{
${ }^{48}$ Kelly, 25.

${ }^{49}$ Valerie Sutter, "Book Reviews," review of Challenging the Status Quo: Public Education in Hawaii by Cecil K. Dotts and Mildred Sikkema, History of Education Quarterly 35, no. 3 (Autumn 1995): 305. (JSTOR).
} 
upset businessmen because it allowed for more freedom culturally, allowing Hawaiians to escape their previously preset destiny as agriculturalists and to pursue careers of their own interest. ${ }^{50}$ Another important change was the improvement in teacher education. This change helped to lift the level and quality of education as a whole. ${ }^{51}$ In addition, educational expansion improved when Hawaii began giving one-fifth of its taxes toward education. $^{52}$

World War II acted as a further catalyst to change within the Hawaiian educational system. Greater standardization of education was required during a period of increased military dominance. Japanese Language Schools were shut down. Additionally, independent and private schools designed themselves more toward college preparation. ${ }^{53}$

Social stratification swelled, pushing the native Hawaiian culture further toward the periphery. ${ }^{54}$ This isolation slowly began to reverse itself as tourism began to dominate the islands, conjuring a powerful native Hawaiian rights movement.

\footnotetext{
${ }^{50}$ Kelly, 30-31.

${ }^{51}$ Ralph Kuykendall and Arthur G. Day, Hawaii: A History from Polynesian Kingdom to American Statehood (New York: Prentice Hall, 1948), 242.

${ }^{52}$ Cecil Dotts and Mildred Sikkema, Challenging the Status Quo: Public Education in Hawaii, 1840-1980 (Honolulu: Hawaii Education Association, 1994), 55.

${ }^{53}$ Kelly, 32-33.

${ }^{54}$ Bell, 106-107.
} 


\section{Hawaiian History Textbooks}

Printing began early in Hawaii. Beginning in 1831, Hale Pa'i printing press was located on and served Lahianaluna, the first public school west of the Rockies. Although Hawaii got off to a fast start, by the mid twentieth century many textbooks used in the public classrooms were old and out of date.$^{55}$ Fortunately, this has changed, as the Hawaiian publishing company, Benjamin Bess, prints and updates many of the textbooks used on Hawaii today. Over approximately the past hundred and fifty years a handful of history texts have served the Hawaiians in educating students about Captain Cook.

Variations in portrayals of Cook are detectable through four major periods on Hawaii, the "missionary", the "plantation", "tourist", and "native Hawaiian movement" periods.

\section{Missionary Era Texts}

Sheldon Dibble, a missionary and instructor at Lahianaluna, was assigned the task, during a meeting of the missionaries in 1831, to collect the facts about Hawaii and write a book on his findings. He employed his scholars, (which included Hawaiians David Malo and S.M. Kamakau) to extract information from elders and the like. ${ }^{56}$ Influenced heavily by the American religious mission he was part of, Dibble took a condemning tone to both Cook and the Hawaiians. Thus, in the late 1820's he became the first to break away from the more benevolent accounts of Cook written by the English and other Europeans decades earlier. His work, Hawaiian Antiquities (Moolelo Hawaii), has been criticized for beginning a long stretch of condemnation on Cook, and believed

\footnotetext{
${ }^{55}$ Lahaina Restoration Foundation, "Hale Pa'i," http://www.lahainarestoration.org/halepai.html (accessed December 7, 2008).

${ }^{56}$ S.M. Kamakua and David Malo were native Hawaiians that enlisted in the missionary school at Lahianaluna. Both went on to become historians. David Malo's work in 1838, written in Hawaiian, was shortly followed by Dibble's a year later.
} 
by some to be the origin of negative portrayals and attitudes regarding Cook upheld by Hawaiians through today. ${ }^{57}$ Dibble's claim that, "Sin and Death were the first commodities imported to the Sandwich Islands" sums up his view on Cook's men and their behaviors. ${ }^{58}$ More specifically on Cook, Dibble's most damaging accusation is that Cook committed the sin of allowing himself to be worshipped. Other descriptions of how Cook and his men used firearms to contain the Hawaiians, and the permitted sexual activities which Cook allegedly participated in himself are used to support Dibble's moral and religious claims against Cook's character. ${ }^{59}$

As evidence of their heathenism, both the Hawaiians tendency to steal and the subsequent use of firearms by the English are established early by Dibble. His account begins with Cook's anchorage at Waimea, Kauai and the events that ensued there. Dibble explains that coming upon the ship the Hawaiians noticed the iron that adorned the British vessels. He cites their glee and over eagerness to acquire it. In this excitement, a Hawaiian warrior was allegedly shot while attempting to steal some of the iron. ${ }^{60}$ This account reveals the immediate use of gunfire by the British. It also adds a larger argument in regard to the manner in which Cook was deified due to the use of firearms.

Dibble connects the use of gunpowder with Cook's deification. He describes that on the succeeding night of Cook's arrival the use of cannons and fireworks were put together for a show. ${ }^{61} \mathrm{He}$ then asserts that, "The people were filled with confusion and

\footnotetext{
${ }^{57}$ John F. G. Stokes, “Origin of the Condemnation of Captain Cook in Hawaii," in the $39^{\text {th }}$ Report of the Hawaiian Historical Society For the Year 1930 with Papers Read at the Annual Meeting (February, 10, 1931), 95.

${ }^{58}$ Sheldon Dibble, History of the Sandwich Islands (Lahainaluna, HI: Press of the Mission seminary, 1843), 21-22.

59 The claims of Cook's sexual relations are contested by most other accounts.

${ }^{60}$ Dibble, 21.

${ }^{61}$ This is not historically accurate according to John Stokes's article "Origin of the Condemnation of Captain Cook in Hawaii."
} 
terror, concluded that the foreigners were superior beings, called the captain a god, and gave him the name Lono." ${ }^{62}$ Dibble explains that from this day forth Cook was known as Lono to the Hawaiians. ${ }^{63}$ This description clearly draws a link between the use of gunpowder and Cook's deification, although Dibble does not comment on it.

Dibble makes his most damaging claim from the Lono story that Cook "allowed himself to be worshipped as a god." ${ }^{, 64}$ Dibble explains that the islanders on Kauai remarked on Cook and his men and their unusual powers with fire and smoke. During the year that Cook and his men headed north, these accounts spread to the island of Hawaii. Dibble reports that, "on the return of Captain Cook, both chiefs and people were disposed to receive him as a god." ${ }^{65} \mathrm{He}$ adds that the Hawaiians ceased trading with Cook and instead filled his ship with the best provisions on the island. ${ }^{66}$ In addition, it is reported that priests crouched toward Cook uttering prayers of worship. Perhaps needless to say is that in Christianity it is a cardinal sin to allow oneself to be worshipped. Dibble claims, "this adoration, it is painful to relate, was conceived without remonstrance."67 Therefore, Dibble's portrayal of Cook may be seen as one of the first departures away from Cook being held in the heroic light cast by European biographers and writers.

Even in describing Cook's death and the preceding events, Dibble maintains the same condemning tone. He claims that he will speak about the death of Cook, "as it develops some traits of the heathen character [Cook], and the influence under which the heathen [the Hawaiians] suffer from foreign intercourse., ${ }^{, 68}$ Dibble explains that Cook

\footnotetext{
${ }^{62}$ Dibble, 21. This is obviously skewed by a Western/Eurocentric and missionary slant.

${ }^{63}$ Dibble, 21.

${ }^{64}$ Dibble, 24.

${ }^{65}$ Dibble, 23.

${ }^{66}$ This is not necessarily true, as the British continued to trade iron and other items.

${ }^{67}$ Dibble, 24.

${ }^{68}$ Dibble, 25.
} 
departed Hawaii, only to return shortly after to refit a broken mast, a sign that God's vengeance was cast upon Cook for his sins. Ironically, Dibble also describes that the Hawaiians were growing uneasy from their loss of provisions and "alienation of their wives. ${ }^{\prime 69}$ The latter claim appears to be a more pragmatic approach that alludes to the sexual indulgences of Cook and his crew, and is designed to support Dibble's condemnatory tone. ${ }^{70}$ However, Dibble overlooks the possibility that the Hawaiian authorities were attempting to befriend Cook, by giving generous provisions, in hope of inter-island hegemony.

The events leading up to Cook's death are described by Dibble. He explains that violence was instigated by some of Captain Cook's men upon a young chief named Palea. The reasons for this are not given. The report follows that Palea then stole a boat from Captain Cook's ship. Dibble explains that this may have been out of revenge for the preceding violence or simply to acquire more iron. Cook and his men then attempted to retrieve the boat; perhaps unaware that it was too late, for the Hawaiians had scavenged it for its iron.

Dibble's description of Cook's death mixes both English and Hawaiian accounts and reveals a statement that attempted to justify Cook's death. He describes Cook going to shore with armed marines to capture the king for collateral, adding detail through the accumulated native Hawaiian accounts. Returning to the shore with the king and preparing to board him, Cook and his men ran into more trouble. Dibble explained that a chief was killed during the incident. Word spread and a brother of the chief began his quest for revenge. Cook fired upon him with his pistol. Confusion ensued. Dibble

\footnotetext{
${ }^{69}$ Dibble, 25.

${ }^{70}$ Dibble, 25.
} 
described that Cook killed a man that had thrown a stone. The chief then took a hold of Cook to contain him. Cook struggled to free himself, and in so doing fell to the ground with a groan. Dibble then writes, "The people immediately exclaimed, 'He groans-he is not a god' and instantly slew him.." ${ }^{, 1}$ The passage from this account remains to be the one that expresses the ultimate moment of realization that Cook is, in fact, not a god, and thereby gives reason for his death; the passage is used in the majority of future textbooks for this purpose. It begs the question however, how did the story of Lono persist if he was determined not to be Lono at this point?

Also noteworthy is Dibble's account of the aftermath surrounding Cook's death. He describes that Cook's men opened fire upon the crowd of Hawaiians that had gathered during the incident, killing many of them. ${ }^{72}$ Later Cook's body was carried to the interior of the island, his flesh burned, his bones kept as part of their custom. Dibble reported that, "The Heart, liver, etc...were stolen and eaten by some hungry children, who mistook them in the night for the inwards of a dog." ${ }^{, 73}$ Could this be native Hawaiian hyperbole? Also pertaining to the aftermath, Dibble explained that for several years after the incident of Cook's death, voyagers refrained from visiting the islands believing the Hawaiians to be "treacherous and bloody." 74 Dibble's account fades on these highlights.

Although the primary governing force in Dibble's writing and criticism of Cook is the Christian religion, it may not have been his only influence. It should also be considered that America had recently won a war against England and bitter attitudes

\footnotetext{
${ }^{71}$ Dibble, 27.

${ }^{72}$ The total number being between 17 and 20 in most reports.

${ }^{73}$ Dibble, 27.

${ }^{74}$ Dibble, 28.
} 
lingered on both sides. Perhaps unknowingly, Dibble provided roots for the Americanization process that later developed in Hawaii. ${ }^{75}$

In regards to Dibble's view on violence and sexual relations, it is clear that Dibble overlooked the reality of eighteenth-century seaboard lifestyle, and especially explorers, who endured many exhausting hours at sea with loosely set destinations. Fortunately writers that followed Dibble were less influenced by religious priorities when expounding upon Cook in Hawaii. Unfortunately, Dibble's condemnation of Cook rooted a negative portrayal of Cook within the Hawaiian society, and his missionary bias influenced Cook's image for years to come. ${ }^{76}$

\section{Transition from the Missionary Era to the Plantation Era}

Forty years after Dibble's work in 1880, Abraham Fornander, circuit judge of the island of Maui and Knight Companion of the Order of Kalakaua, offered a less religiously biased account than Dibble's that highlighted the Hawaiian accounts of S.M. Kamakau and David Malo. ${ }^{77}$ Fornander, originally from Sweden, was married to a Hawaiian, well versed in the history of Pacific voyages, and linguistically adept. These attributes helped Fornander's work serve as an important tool for pulling Cook's portrayal out of the grasp of the missionaries, and provided a more balanced account. His text addresses the Hawaiians' fraternization with the British, issues regarding theft, violence, and sexual relations during Cook's time in Hawaii. Fornander also served as the

\footnotetext{
${ }^{75}$ As mentioned in previous notes, a debate over whether or not Cook was the first European to discover the Hawaiian Islands was common in many of these early accounts until Dahlgren's publication in 1916. ${ }^{76}$ Dibble, 24.

${ }^{77}$ The Knight Companion of the Order of Kalakaua was an honorary position given by the King/Queen.
} 
first inspector general of schools, as a result of the Reorganization Act of $1865 .{ }^{78}$ His involvement in education indicates that his text may have been used in much the same way Dibble's was, as a teacher's aid, but it is difficult to know to what extent. Fornander wrote a three-volume Polynesian history, and its value as a source can be seen in later crucial works such as those by Ralph Kuykendall.

The most important point about Fornander's text is that he argues strongly against early historians David Malo, Sheldon Dibble, and S.M. Kamakua and their perspective that Cook's death was an act of divine punishment because Cook allowed himself to be worshipped. He asserts that Cook was unaware of Hawaiian customs, and had gone through similar ceremonious events on other islands that would be comparable. ${ }^{79}$ It is also noteworthy that Polynesians throughout the Pacific worshipped various forms of Lono, and the connection of Cook to the Hawaiian god Lono is subject to multiple interpretations. ${ }^{80}$ Overall, Fornander's explanation corrects the overtly Christian tone used by Malo, Dibble, and S.M. Kamakua, and makes for better history.

Fornander fits his discussion of Cook within a Hawaiian context rather than a European or American one. ${ }^{81}$ This is an important change in the overall perspective to Cook's arrival, because he arrived during a period of inter-island war between chiefs on Maui and Hawaii. Fornander writes:

\footnotetext{
${ }_{78}^{78}$ Day, 198.

${ }^{79}$ Abraham Fornander, An Account of the Polynesian Race: Its Origin and Migrations, and the Ancient History of the Hawaiian People to the Times of Kamehameha (Honolulu: Bishop Museum Press, 1909), 180-181.

${ }^{80}$ Terence Barrow, Captain Cook in Hawaii (Honolulu: Island Heritage Limited, 1976), viii. Barrow explains that 50 forms of Lono existed throughout Polynesia during Cook's expeditions.

${ }^{81}$ Fornander utilizes both Cook's journal alongside Captain King and others, but relies more on Hawaiian "reminiscences" that he feels "gives a more natural, and consequently a more probable account of the transaction" between Cook and the Hawaiians.
} 
It was during the early part of this [war] campaign of 1778 that the English discovery ships 'Resolution' and 'Discovery,' under the command of Captain James Cook, arrived at these islands... ${ }^{82}$

This 'inter-island warfare' perspective is key to understanding later interpretations of Cook's treatment by and fraternization with the Hawaiians during his visits.

Cook's orders to protect the natives against disease are examined and evaluated by Fornander. He explains that native historians, Malo and Kamakua, found great disgust in the introduction of venereal disease to the Hawaiians, and were quick to judge Cook for his lack of discipline. Fornander comments that despite the natural inclination to condemn Cook, their arguments are "ex post facto" and that they do not take notice of the times and the circumstances under which Cook and his seamen were placed, nor of the social condition, customs, and modes of thinking which at the time obtained among the Hawaiians. ${ }^{83}$

However, Fornander ultimately believed that despite the fact that Cook may have issued orders for sexual abstinence, the execution of those orders fell short. Nonetheless, his explanation again helps to delineate between his work and the missionary influenced work of Malo, Dibble, and Kamakau.

Fornander presents the Hawaiians' lust for iron and the resulting consequences of their absconding with it. Apparently the Hawaiians had a previous familiarity with iron by some means, although it is not certain how. ${ }^{84}$ Fornander uses Kamakau's description of the scenario. Kamakau reveals that the Hawaiians spotted the amount of iron upon the ships and decided on taking it. A warrior of the chiefs exclaimed, "I will go and take

\footnotetext{
${ }^{82}$ Fornander, 157.

${ }^{83}$ Fornander, 162.

${ }^{84}$ It is noted in most texts that they acquired it through pieces of it attached to drift wood that would wash ashore. There are variances in the stories and description of the size of the iron pieces on the island when Cook arrived.
} 
forcible possession of this booty, for to plunder is my business and means of living" ${ }^{\prime 85}$ The chief granted the warrior permission to go. The warrior managed to get aboard the ship and make away with some of the iron. Consequently, he was shot.

In conjunction with the English's use of gunpowder and the story of Cook as Lono, Fornander reveals early indications of fraternization with the Hawaiians. He explains that on the same night, after the warrior was shot for attempting to steal iron, guns and fire rockets were let off. Consequently, "The natives believed it was a god, and they called his name Lonomakua, and they thought there would be war." ${ }^{86}$ A chiefess then replied that they should befriend their god, not fight him. This would bring more fortune to them. This chiefess then gave her own daughter as a woman to Lono, and Lono allegedly slept with her. Fornander's account follows that the Kauai women then prostituted themselves to the foreigners for iron. ${ }^{87}$ Obviously, there are a few important issues here. First, Fornander's account of fraternization introduces a link between the English's use of gunpowder and the decision made by the Hawaiians to befriend Cook and his men. Second, the allegation that a Hawaiian woman was given to Captain Cook and that Cook slept with her is much different than accounts of his sexual abstinence in all European sources. Finally, the claim that Hawaiian women traded their bodies for iron is an important factor to consider in the historical account of this event and its consequences. It should be noted that, culturally this was acceptable behavior for Hawaiian women at the time. ${ }^{88}$ However, it should also be noted that it was nearly sixty years after Cook's visit that Hawaiian accounts were recorded, and the reputation of

\footnotetext{
${ }^{85}$ Fornander, 168.

${ }^{86}$ Fornander, 168.

${ }^{87}$ Fornander, 169.

${ }^{88}$ Fornander, 169.
} 
fraternization may have been important to Hawaiians during the time of Cook's visit as well as during the time of the account taking. ${ }^{89}$

Fornander's contributions to Cook's portrayal are important to summarize for a general understanding of the transition from the missionary era into the plantation era. His work marks a turning point away from the condemnation from the missionary era. However, writing just before the American annexation, Fornander still held onto much of the information given in the Hawaiian accounts recorded afterwards. The combination of the two allowed for Cook's portrayal to be inflated by exaggerations and falsities. Nonetheless, Fornander set forth a more progressive movement of Cook's portrayal. At the request of the Board of Education, William Dewitt Alexander created $A$ Brief History of the Hawaiian People in 1891. Like the works of Dibble and Fornander before him, Alexander's text was most likely used as a guide and reference for educators. A historian and teacher, he explains in his preface that he "endeavored to write a simple and concise history of the Hawaiian people, which it is hoped, may be useful to the teachers and higher classes in our schools." 90 As a native born Hawaiian, Alexander asserts that his work takes the position of a patriotic Hawaiian, and that it is written for the young people of his country and not foreigners. In addition to utilizing works by David Malo, S.M. Kamakau, and Judge Fornander, he uses the accounts given by Cook and his crewmembers. ${ }^{91}$ His aspiration was for his text to be a stepping-stone for further works, and this became true with Ralph Kuykendall's voluminous work that followed.

\footnotetext{
${ }^{89}$ Stokes, 69.

${ }^{90}$ William DeWitt Alexander, A Brief History of the Hawaiian People (New York: American Book Company, 1891), iii.

${ }^{91}$ Stokes, 72.
} 
Although influenced by the plantation era leaders movement of Americanization, Alexander makes several valuable additions to the progress made earlier by Fornander in pulling Cook's portrayal away from the condemnatory grasp of the missionaries. ${ }^{92}$ While asserting a progressive nature to Hawaii's new relationship with western cultures, Alexander conjures up issues regarding fraternization and social stratification. These issues help to explain how Cook was worshipped, as well as provide elements that both convolute and deconstruct the Cook as Lono story.

Alexander's support of Hawaii's relationship with western civilizations connects his work to the Americanization process. Explaining that Cook's discovery was a turning point in Hawaiian history, Alexander states that, Cook's discovery "ushered in a new era of unexampled progress." 93 He also refers to Cook as "a great navigator" who had already made two world voyages and was now on his third to find a northern passage from the Pacific to the Atlantic. ${ }^{94}$ These praises may appear trivial, but more evidence of Alexander favoring civility provides support to his influence in shaping Hawaiian history. Especially revealing is the way Alexander chooses to convey violence to his reader. In his description of Lieutenant Williamson's initial search for a source for water, Alexander describes their outing:

About noon he [Williamson] returned and reported that he had found a good watering-place, but that on attempting to land in another place, 'the natives had pressed so thick upon him, trying to take away the oars, muskets, and every thing else they could lay hold of, that he was obliged to fire, by which one man was killed.' 95

\footnotetext{
${ }^{92}$ The meaning of Americanization is two fold. It is the loyalty to American culture and religion, and it is the internalization of democratic values.

${ }^{93}$ Alexander, 104.

${ }^{94}$ Alexander, 104.

95 Alexander, 105.
} 
Alexander's tone makes the reader feel as if Williamson had no other choice but to fire his weapon. Interestingly, throughout the remainder of Alexander's discourse on Cook, he casts a light of justifiability upon the civilized officers' use of violence on the native Hawaiians. In contrast, he denounces the lowly sailors who rampage a village with fire after Cook's death. Thus, Alexander retains a balanced account while favoring civility. This type of favoritism continues as he encompasses elements of fraternity and social stratification into his writing, and thereby creates an early connection to the Americanization process.

Contributing more detail to the Hawaiian's fraternization of Cook and his men, Alexander separates the story of Captain Cook directly after the broader story of the battles that were occurring between the three main rulers of the islands. Through this approach Alexander reveals the background of Kamehameha's rise to power. The young Hawaiian prince "distinguished himself in these [early war] campaigns as a brave and skillful warrior." ${ }^{96}$ Kamehameha then befriended Cook, his men, and other westerners who would assist him in becoming the first ruler of all the Hawaiian Islands. By establishing the Hawaiian state of affairs at the time of Cook's arrival, and connecting the rise of a skillful warrior to western progressiveness, Alexander clarifies the reasons to why the fraternization with Cook and his men took place. ${ }^{97}$

Alexander offers insight into the social stratification of Hawaiian islanders at the time of Cook’s arrival at Kealakekua Bay. According to Alexander, Hawaiian priests played a major role in the installation of Cook as Lono. He explains that, "Whenever he [Cook] went on shore one of the priests accompanied him with a wand in his hand,

\footnotetext{
96 Alexander, 103.

${ }^{97}$ Kamehameha was the first king to unify the islands under one ruler. This action helped to further connect Hawaii to worldly affairs.
} 
ordering all people to prostrate themselves, and sacrifices were offered to him." ${ }^{, 98}$ As a result, the demand of supplying the British became burdensome to many of the subservient Hawaiians. In addition, Alexander's account becomes the first to describe that Cook's crewmembers were also believed to be supernatural beings; and although he doesn't specify whether or not the priests were responsible for encompassing Cook's entire crew into this elevated status - he does reveal the events that suggest their influence. ${ }^{99}$ For example, when William Watman, a common sailor died from a stroke, the Hawaiian priests demanded that his body be buried at one of their temples with an elaborate funeral service. ${ }^{100}$ Despite the attempt of the priests to treat Watman's passing as a spiritual misfortune, doubts began to surface over the validity of Cook's crew being supernatural beings. ${ }^{101}$ Nonetheless, gift giving is reported to have continued throughout the British's stay on the islands. Therefore, in service to their King, Kalaniupuu, the Hawaiian priests acted as protectorates, attempting to elevate Cook and his men to a divine status in order to befriend them. Thus, Alexander connects the story of Cook as Lono with the priests' superiority and Hawaiian commoners' frustration.

By blending Hawaiian and foreign accounts, Alexander created one of the fairest accounts of Captain Cook of the nineteenth century. His efforts continued to eliminate the condemnatory residue left by the missionaries. Alexander, furthermore, began to portray Cook's impact on Hawaii in a more positive light.

\footnotetext{
${ }^{98}$ Alexander, 109.

${ }^{99}$ Other accounts note the worship of Captain King and Lieutenant Williamson.

100 Alexander, 110n

${ }^{101}$ Alexander suggests that Watman's death in conjunction with another incident, one where Cook's men overextended the Hawaiians' generosity of allowing them to take a fence of a temple to use as firewood, the Hawaiians
} 


\section{Plantation Era Texts}

During the plantation period, Hawaii witnessed greatly expanded trade and increased social order, including a more structured educational system. In this era, one of the most influential textbooks about the history of Hawaii, which was widely used in Hawaiian classrooms, was A History of Hawaii (1926) by Ralph S. Kuykendall. According to the preface, Kuykendall and his co-author Herbert E. Gregory were assigned the task of creating a textbook of the Hawaiian history. This task was set in motion by the laws enacted in 1921 and 1923 by the Legislature of the Territory of Hawaii. Required by law, this legislature established the Historical Commission to see to it that a textbook be written. It is difficult to say to what extent A History of Hawaii was used, and without access to such records it may only be surmised. A safe estimate of the grade level as to which the textbook would be used is high school. Although intended to function also as a history of Hawaii for the general reader, questions are provided at the end of each section. Section four entitled "Captain Cook and the Discovery of the Hawaiian Islands" is about ten pages long and briefly outlines Cook and his landings.

Kuykendall's contributions to the portrayal of Cook's time in Hawaii are both progressive and waylaying. First, he provides a background on Cook's life and career, and places Cook's arrival in Hawaii in an Imperial era context. Although this adds a broader look at worldly affairs during the end of the eighteenth century, Kuykendall sacrifices the inter-island context that both Fornander and Alexander established earlier. Second, he reinforces yet simultaneously convolutes the Cook as Lono story. Third, he elaborates on the Hawaiians' obsession with iron, trade between the two cultures, and the events that resulted. In regards to trade misfortunes, Kuykendall softens the tone of 
conflict and violence; and, in addition, he completely omits the topics of disease and sexual transactions. Fourth, he provides an opportunity for a better understanding of the social stratification and cross-cultural complexities through the critical thinking questions at the end of his chapter. Finally, Kuykendall acts as an agent of the Americanization process through his questions aimed at targeting the British and uplifting the American ideal.

After including a brief yet thorough background on Cook's life, including his humble origins and rise to service in the British Navy, Kuykendall presents Cook's encounter with the Hawaiians in the context of eighteenth century imperial expansion. Kuykendall describes Cook's earlier voyages of discovery to areas around such places as Tahiti and Australia; he then explains the importance of finding a passage around North America. ${ }^{102}$ He states that England would benefit most from such a passage, allowing it to reach Asia quickly favoring their trading relationship. Kuykendall's context also gives fluidity to the story, explaining how Cook and his crew had sailed from the Society Islands in early December and had anchored outside of Oahu and Kauai in mid-January. Through this broader context Kuykendall creates a situation where Cook's appearance in Hawaii is less of a sudden and mysterious occurrence, as it is often related in texts.

Unfortunately, Kuykendall does not include the inter-island warfare occurring among the Hawaiians as part of his context.

Despite a lack of explanation, Kuykendall upholds the story of Cook as Lono.

For example, in describing Cook's arrival he uses the quote, "It is at Waimea, on Kauai,

\footnotetext{
${ }^{102}$ Dibble, Fornander and Alexander make mention of the Northern Passage, but they did not put it into a context of British imperialism the way that Kuykendall has.
} 
that Lono first arrived...",103 Although simple, this passage tends to reinforce the notion that Cook was believed by the Hawaiians to be Lono. In addition, he claims that upon their landing Cook was "treated with religious veneration by chiefs and common people alike," and was made the center of an elaborate ceremony. ${ }^{104}$ Furthermore, Kuykendall boldly asserts that, "There can be no doubt that at first the Hawaiians looked upon Cook as the incarnation of their god Lono, though this fact does not seem to have been understood by the Englishmen." ${ }^{105}$ Oddly, this emphatic claim comes with little explanation as to why Cook was worshipped. It does however aim to free Cook from the condemnatory accounts of the missionary era. Furthermore, Kuykendall makes no mention of the violence that took place during the initial encounters between the British and Hawaiians, nor does he describe the fraternization linked to inter-island warfare. He does however discuss trade between Cook and the Hawaiians with more care.

In his description of trade, Kuykendall develops a focus on the Hawaiians' obsession with iron, thus adding more value to the British barter wares. He describes the first scene of encounter where metal is thrown overboard to the Hawaiians down below in their canoes. He quotes Cook, "“I tied some brass medals [and later iron nails] to a rope and gave them to those in the canoes, who, in return, tied some small mackerel to the rope as equivalent. This was repeated." "106 This first exchange between Cook and the Hawaiian fishermen sounds balanced and fair. Kuykendall continues to present trade in a fair light explaining by Cook's words that, "They went, and when they came to the ship

\footnotetext{
103 Kuykendall, 55.

104 Kuykendall, 56.

105 Kuykendall, 56.

${ }^{106}$ Kuykendall, 54.
} 
they saw the iron that was attached... and greatly rejoiced at the quantity of iron." ${ }^{\text {"107 }}$ The Hawaiians zeal for iron is not new to historical accounts, but Kuykendall's focus upon it in this manner adds value to the British side of barter, and in a sense the "civilized" world in general. The significance of Kuykendall's position on iron is further revealed by the consequences that resulted from the Hawaiians' obsession with it.

The consequences of trade were costly for both the British and Hawaiians. Fleeing the harsh winter storms encountered on their search for the Northern Passage Cook and his men returned to the Hawaiian Islands in late November. ${ }^{108}$ This time Maui was the first sighted island, and trade was again free flowing. At this time the king of the Island of Hawaii, Kalaniopuu, and his men (which included Kamehameha) boarded the ships. Oddly, Cook forced his men not to anchor for nearly two months, instead they tacked around Maui and Hawaii. Although Kuykendall describes this scenario, he does not ponder its unusual nature. With an entire crew longing to land, why would Cook do such a thing? Finding a safe place to harbor was a main concern, but it has been hypothesized that Cook was losing touch with his crew and growing weary. ${ }^{109}$ It has also been hypothesized that Cook knew that he did not have enough iron to continue trade which would have put him and his men in grave danger. ${ }^{110}$ Eventually Cook and his men worked around the islands until they found a suitable harbor at Kealakekua Bay. Here, Kuykendall explains, during this second encounter, "unpleasant incidents" began to occur. He attributes this to several factors, and words it carefully. He writes that it was in

\footnotetext{
${ }^{107}$ Kuykendall, 55.

${ }^{108}$ Kuykendall, 55.

${ }^{109}$ Beaglehole, The Life of Captain James Cook, 640.

${ }^{110}$ Beaglehole, The Life of Captain James Cook, 647.
} 
part from the Hawaiians' tendency to take things (steal), but, as Kuykendall points out, it was more from the misunderstandings of cross-cultural communication. ${ }^{111}$

Many Pacific Islanders, Hawaiians included, based their social structure with less concern toward ownership of material objects than Europeans. ${ }^{112}$ Therefore, thieving was integrated into their social dynamics, and although Kuykendall does not mention it, Cook was aware of this. Kuykendall adds to the scenario of "unpleasant incidents" with his own impression when he states that, "It was also likely that some of the Hawaiians came to doubt that Captain Cook was a god." ${ }^{, 13}$ He however provides no reason for such an assertion. Kuykendall then explains that Cook and King Kalaniopuu managed to maintain peace among their people. ${ }^{114}$ Much like Alexander, Kuykendall establishes a growing tension prior to their first final departure. Cook and his men departed from the islands, but facing adverse weather and an injured mast they returned. During the third visit Kuykendall describes that, “...the ships were not received quite as cordially as before and serious quarrels broke out." ${ }^{, 15}$ He then explains that a boat was taken from the Discovery and ripped apart for its iron. Cook responded with action. A blockade was put on the bay where they lay anchored. Next, a mission to retrieve the king and hold him hostage on board the Resolution failed. Kuykendall describes that Kalaniopuu's wife and several other chiefs tried to keep the king on shore. He claims that a quarrel broke out which led to blows. Kuykendall states that around the same time "a chief entering the further side of the bay without knowing about the blockade was killed by a shot from one of the

\footnotetext{
${ }^{111}$ Kuykendall, 58.

112 Cook was aware of this tendency throughout the Pacific.

113 Kuykendall, 58.

${ }^{114}$ Kuykendall, 58. Gifts of great value were then given on their departure.

115 Kuykendall, 58.
} 
boats." ${ }^{116}$ News of this spread quickly. The result was the death of Cook, several of his men, and approximately twenty Hawaiians.

As an example of how Kuykendall presents issues of social stratification and cross-cultural complexities, I have chosen three of the five questions asked at the end of his chapter. These questions also bring together other elements of Kuykendall's account such as trade, Cook as Lono, imperialism/globalization, and Americanization. The third question asks:

If you had been a Hawaiian and awoke one morning to find Captain Cook's ship at anchor in the bay, how would you have felt? If you had been a chief, what would you have done? Why? If you had been a poor commoner who has a small taro patch, what would you have thought? What would you have done? Why?

The fourth one requests:

Show how each of the following made it impossible for the English and Hawaiians to understand each other's actions and led up to the event which caused Captain Cook's death:

a. $\quad$ Each group spoke a different language.

b. The Hawaiians desired, above all things, to possess iron.

c. The English looked on stealing as a crime which deserved capital punishment.

d. The Hawaiians had never seen so large a ship or men who looked like the English.

e. The English sailors were rough and ignorant men.

f. The Hawaiians did not feel that it was wrong to take from someone else a thing that they wanted.

g. The English did not realize that the Hawaiians thought Cook was a god.

The fifth question states and then asks:

In the time of Cook, a northwest passage would have given to the country which controlled it great power. Why? To-day the large countries of the world are hunting for land in which there is oil. Can you explain why? Can you imagine what troubles would arise if oil was found in a rather small unprotected country ${ }^{117}$

\footnotetext{
${ }^{116}$ Kuykendall, 58.

${ }^{117}$ Kuykendall, 60-61.
} 
These questions help open up the discussion on Kuykendall's account. The third question prods Hawaiian students to think about the social stratification in their homeland at the time of Cook's arrival. Kuykendall provides an opportunity to critically think from two very different positions within the Hawaiian society, and, although he does not directly address issues of fraternization and food depletion within his account, they could easily be extracted from this question. The fourth question introduces the complexity of communication and cross-cultural interaction between the two groups. As mentioned previously in regards to trade, part 'b" of question four, which states, "The Hawaiians desired, above all things, to possess iron," reasserts Kuykendall's aim to elevate the value of Cook's possession of iron. Question five turns the student's attention to issues of imperialism and globalization; a profound question that is applicable even in our time. However, I believe that Kuykendall reveals himself as a contributor to the Americanization process through this last question, especially the final segment of it. I believe that Kuykendall's fifth question reinforces the protectorate position that America had taken regarding the Hawaiian Islands.

Written in a time when both American business and government were progressing on the Hawaiian Islands, Kuykendall's account reflects the two-fold process of Americanization. On one side, the institutionalization of the Hawaiian culture was being controlled by burgeoning governmental structures aimed at protecting the Islands with American education and value systems. On the other side, American business controlled the Islands through their economical stronghold. Kuykendall's reflects these forces by positively portraying western culture. For example, by upholding the Cook as Lono story, Kuykendall chooses not to account for the link between the use of firearms and Cook's 
deification. This may also be said for the absence of the account of disease that was first brought by Cook and his men, but more thoroughly transmitted by Americans and other foreigners coming thereafter. These omissions act favorably on western culture, and thereby add to the Americanization process. In addition, concentrating on the Hawaiian lust for iron, Kuykendall manages to create a bridge between a native society without and a civilized society with. Furthermore, passages such as the one explaining that the islands were unknown to the "civilized [my italics] world of Europe, America, and Asia" add a tone common to the Americanization process. ${ }^{118}$

As Kuykendall's work brings this analysis into the twentieth century, I would like to review a few points about his account and put it into context. First, he establishes a major shift away from the missionary era's work by his claim that Cook and his men were unaware of Cook's divination. Second, Kuykendall lessens the portrayal of violence and thus stifles the connection that can be drawn between the use of firearms and Cook's divination. Third, a complete omission of disease and sexual relations is made. Fourth, although Kuykendall's imperial context contributes to understanding the global picture at the time, he does so by sacrificing the context of inter-island war, which is crucial to understanding the Hawaiian perspective on the event.

\section{The Tourism Era}

Before continuing with this chronological investigation let me introduce a critical article in describing the tourism era's influence of Captain Cook's portrayal in Hawaii. Julie Kaomea’s “A Curriculum of Aloha? Colonialism and Tourism in Hawaii’s Elementary Textbooks," pertains to both Hawaiian education and Captain Cook. Kaomea

\footnotetext{
${ }^{118}$ Kuykendall, 52.
} 
is an assistant professor at the University of Hawaii at Manoa and advocate for Native Hawaiian rights. Her article focuses on what she believes to be a misrepresentation of Native Hawaiian culture in textbooks. Kaomea argues that "the stereotypical depictions of Native Hawaiians" are designed to serve the "economic interests of the state by fulfilling its need for cheap labor, docile Hawaiians, and willing and able 'ambassadors of aloha." ${ }^{\prime 119}$ She claims that these depictions are a result of colonial representations made by Captain Cook and other early visitors, and have been sustained into the twentyfirst century via the tourist industry. Kaomea's article provides a historical backdrop of Hawaii's education system, analyzes a few textbooks against a tour guide paradigm, and then explains what is left 'unsaid' in many of these historical accounts.

Kaomea provides a useful overview to the history of Hawaii's education system as it pertains to her argument. She explains how "Over time, the 'missionaries' religious aspirations gave way to more economical ones. ${ }^{, 20}$ She asserts that schools became a social mixing ground for the large number of immigrants and Hawaiians. However, Kaomea then explains that American annexation in 1898 soon led to the realization that importing labor was a "wasteful policy" and thus directed the education of Hawaii's children to be geared toward making them semi-skilled agriculturalists, and, thereby kept them chained down from any upward social mobility. ${ }^{121}$ This pattern continued as tourism began to dominate the economy.

Native Hawaiian movements also began to rise, and during the 1960's Hawaiians and others in the community demanded more Hawaii-oriented courses. Kaomea explains that a decade later Native Hawaiians' lobbying for more representation in textbooks paid

\footnotetext{
${ }^{119}$ Kaomea, 324.

${ }^{120}$ Kaomea, 322.

${ }^{121}$ Kaomea, 323.
} 
off. A 1978 state constitutional amendment mandated that a Hawaiian educational program allot monies to the State Department of Education to develop such a program. Consequently, all public schools in Hawaii, kindergarten through grade 12, were required to provide their students with instruction in Hawaiian culture, history, and language. Curriculum guides were developed to include the study of Hawaii for the fourth, seventh, ninth and eleventh grades' curriculum. Textbooks were then altered to meet these guidelines. Kaomea adds that Hawaii is the only state with a single centralized school district. Despite centralization, teachers and schools do have certain instructional autonomy, especially in selecting textbooks. However, no statewide approval mechanism is in place, and schools are often left to choose textbooks according to their available funding. This means that old and outdated textbooks are repeatedly used.

Aimed at revealing the tourist industry's influence on textbooks, Kaomea analyzes Helen Bauer's Hawaii: The Aloha State (1960), and Hawaii: Our Island State (1979) by Norris Potter and Lawrence Kasdon. Because these texts were purchased extensively as a result of the 1978 State mandate they entered the classrooms in a flood. Unfortunately, even with a few revisions made over the past fifty years since their first printing in 1960, they have remained much the same. In addition, Kaomea reveals that many fourth grade school teachers continued to use Bauer's text because of its comprehensiveness and the fact that it came with a workbook.

Kaomea's analysis of Bauer's text displays an uncanny similarity between the school textbook and tourist propaganda. The first clue is that the title of Bauer's book is remarkably similar to many travel guidebooks. In addition, the covers of travel guidebooks appear much the same. Kaomea continues by revealing that Bauer's text is 
divided into chapters that are destination orientated such as, "Oahu, The Gathering Place," and "Maui, The Valley Island." The similarities continue to stack up in favor of Kaomea's argument. She shows that each island chapter is further subdivided into subsections that mimic a tourist guidebook. For example, "The subsection section, 'Adventure and fun at Waikiki' states that 'shopping along the main street of Waikiki...is a 'must' for all tourists' and, 'No holiday...is complete without going to at least one luau.' Indeed, as Kaomea notes, "these are curious statements," to be found in a textbook. $^{122}$

Her examination of Bauer's text continues by comparing images, and is equally revealing. By placing textbook images alongside scenic postcards she again finds a striking similarity. One may wonder with a place as beautiful as Hawaii perhaps if this is just coincidental. However, Kaomea shows that this is perhaps not the case, as some of the images within the text are credited to the Hawaii Visitors Bureau. Added to this is Kaomea's account that the textbooks also provide "a pronunciation guide to Hawaiian words, and a calendar of Hawaii's holidays and festivals which travelers can use to plan their stays in accordance with Aloha Week, Lei Day, Kamehemaha Day, or other special island events." 123 I must add that although Kaomea's argument is sound for the most part, she may be overlooking the fact that many "Hawaiians" (native, part, and non) travel from one island to another for such events. ${ }^{124}$ In other words, the Hawaiians themselves are among the island tourists.

\footnotetext{
122 Kaomea, 326.

${ }^{123}$ Kaomea, 331.

${ }^{124}$ While on Maui I spoke with a few Hawaiians that had traveled to Lahaina just for the huge Halloween celebration that was occurring.
} 
Kaomea also looks at revisions of texts, such as Bauer's Hawaii: The Aloha State (1960), to Bauer/Rayson's Hawaii: The Pacific State (1997). She describes that for the most part the text is the same however there are updated sections on the overthrow of the Hawaiian monarchy by the United States, the fight for native lands, and the movement towards Hawaiian sovereignty. Kaomea states that, "In essence these politically correct revisions are merely cosmetic add-ons overlaid on top of the original tour book structure." ${ }^{125}$ I agree with Kaomea on this point; as I will show in my later analysis of the Bauer/Rayson edition, the subtle changes that do occur are orientated toward implementing a stronger, yet superficial, Native Hawaiian viewpoint. Most importantly, the revisions do not deconstruct the tourist book model set in place nearly fifty years earlier.

Kaomea uncovers the same tour book structure in Hawaii: Our Island State (History of the Hawaiian Kingdom), written in 1979 by three Hawaiian residents, Norris W. Potter, Lawrence M. Kasdon, and Dorothy Hazama. ${ }^{126}$ Kaomea relays that the preface states, "the book was published to fill a need for instructional materials about Hawaii which are written specifically for Hawaii’s students." ${ }^{127}$ Kaomea then shows how this proclamation takes a drastic detour. The preface continues explaining that, "while the book was written with the needs of Hawaii's school children in mind, it also was written so that it might be useful to visitors to Hawaii who are looking for a concise description and history of the islands." ${ }^{, 28}$ Kaomea explains that the familiar tour book structure

\footnotetext{
${ }^{125}$ Kaomea, 331.

${ }^{126}$ Hawaii: Our Island State later morphed into History of the Hawaiian Kingdom.

${ }^{127}$ Norris W. Potter, Lawrence M. Kasdon and Dorothy Hazama, Hawaii: Our Island State (Honolulu: Bess Press, 1979); Norris W. Potter, Lawrence M. Kasdon, and Ann Rayson. History of the Hawaiian Kingdom (Honolulu: Bess Press, 1983), as cited in Kaomea, 331.

${ }^{128}$ Norris W. Potter, Lawrence M. Kasdon and Dorothy Hazama, Hawaii: Our Island State (Honolulu: Bess Press, 1979), iii, as cited in Kaomea, 331-332.
} 
includes a map of major tourist attractions and a section on language and place names that is curiously entitled "Have You Visited These Places?" Kaomea's argument is convincing, but again I suggest that perhaps it is useful for inter-island travel, and that Kaomea may be slightly too vigorous in her battle against perpetuated tourism.

This may all seem overly tangential to our focus on Captain Cook, but Kaomea brings us full circle claiming that the hospitable Hawaiian image began with Cook. She states that, "this tourist-catering mentality has been with us for hundreds of years, ever since it was first taught to us by Hawaii's very first tourist, Captain James Cook." ${ }^{129}$ Again, I feel like Kaomea may be overly emotional here; working under the auspices of both the Royal Navy and the Royal Society, one doubts that Captain Cook would have thought of himself as a tourist.

Kaomea's case is also weakened by a lack of balanced evidence. To illustrate the portrayal of happy Hawaiians upon Cook's arrival, Kaomea uses the quote: "Natives came out in their canoes to meet us. They seemed very happy that we had come."130 However, she uses this statement in isolation to build her case. Kaomea describes that the welcoming scene portrayed between Cook and the Hawaiians is familiar to her. She explains that, "it is familiar because this scene of happy natives rushing out to greet visiting foreigners has been represented and reenacted countless times since the arrival of that first tourist [Cook]." ${ }^{, 131}$ Kaomea's error is that she does not follow up on the rest of Bauer's account. Bauer does describe, albeit scantily, some of the conflict, including Cook's death, which arose between the English and the Hawaiians. This offers balance to

\footnotetext{
${ }^{129}$ Kaomea, 332.

${ }^{130}$ Kaomea, 332.

${ }^{131}$ Kaomea, 332.
} 
the story of Cook and the portrayal of foreign encounter, and I feel that it should be taken into account as we proceed with analyzing Kaomea's argument.

Kaomea uses another example that falls short as solid evidence that Cook and his men propagated the attitudes that she charges them with. Kaomea describes the artwork by John Webber, in particular his watercolor entitled "A View of Karakakooa in Owhyhee." She claims that, the image has been used in exaggerated forms to "advertise early cruise liner travel to Hawaii in the 1920's and 1930's... and is currently reenacted hundreds of times a day at our Honolulu international airport as lei greeters in Hawaiian costumes rush from gate to gate to give a royal welcome to our visitors arriving in tour groups."

It may be true that exaggerated forms used by the tourist industry have further indoctrinated Hawaiian hospitality and "aloha spirit," but Webber's original is modest in portraying any such "royal welcome." Kaomea also overlooks other works by Webber, especially the one of Cook's death. Webber's painting, as well as the element of Cook's death in general, is found in most textbooks and is counterintuitive to Kaomea's argument.

Kaomea's subsection titled "The Unsaid" discusses what is left out of textbooks. Unfortunately, as important as this topic is, Kaomea is again selective in her approach. She explains that, "When one reads the children's Hawaiian studies books alongside the logs and journals of Captain Cook and his men one notices all that is omitted or unsaid in these textbooks." This is undoubtedly true, but it must be added that when one reads the native Hawaiian accounts from S. M. Kamakua or David Malo, there is even more left

${ }^{132}$ Kaomea, 332, 334. 
out of the textbooks. ${ }^{133}$ Both of these truths make for discussion, but Kaomea focuses only on the former. Kaomea uses a few random examples of what is left unsaid in textbooks to bolster her argument. These examples, however, reveal her lopsided view even more. She begins with describing the "litany of punishments that Cook and his men inflicted upon the Polynesians in order to create an initial sense of terror among them and thereby assert their superiority over these barbarians." What is left out, according to Kaomea, is the flogging of "Polynesian commoners and high-ranking chiefs alike...for the suspected theft of nails, hooks, and other small iron items."134 Two things stand out here. One, she has come to suddenly include all of the Polynesians in her argument. Two, the "suspected" theft of what she makes out to be trivial objects does not include the Discovery's cutter nor important navigational tools, such as those taken on Tahiti during their first voyage. Despite these oversights what she is saying is important in its essence. She continues in her assertion, "What is left unsaid is how Third Lieutenant Williamson shot a young Hawaiian chief to death just minutes before Cook first stepped ashore in Waimea, Kauai."135 I strongly agree, but Kaomea overlooks other important details and possibilities.

Various accounts of Cook's time in Hawaii, along with the historical accounts of other Polynesian encounters, provide details and possibilities that weaken Kaomea's argument. To begin, Kaomea leaves out the possibility that Williamson was provoked by an overwhelming group of natives that had swarmed into his boat. In addition, Williamson, allegedly, had an entirely different belief in how to approach the natives. He

\footnotetext{
${ }^{133}$ The missionary influence of these accounts, compounded with the fact that they do not appear until nearly sixty years after Cook's death, produce skewed and often exaggerated works.

${ }^{134}$ Kaomea, 337.

${ }^{135}$ Kaomea, 337.
} 
thought that by initially instilling fear less accumulative damage would be done. Kaomea discusses none of this. It may also be noted that "Polynesians" had a tendency to test others in their willingness to defend themselves, and this led to their later respect. Nonetheless, Kaomea uses these examples of the British aggression to sell her case. For example, she states:

After this first fatal lesson in the power of firearms it is no wonder that when Cook first stepped ashore in Hawaii with Williamson at his side he was greeted by submissive Hawaiians who 'fell flat on their faces, and remained in that humble posture till [Cook] made signs for them to rise.'... It is no wonder that Cook and his men found the Hawaiians to be polite, hospitable, fearful of giving offense, eager to please, and sensible of their own inferiority. ${ }^{136}$

Kaomea's point is important. Perhaps the incident with Williamson did encourage a type of obedience by the Hawaiians, but perhaps this peaceful obedience is exactly what the English hoped for to maintain order in the long run. Moreover, Kaomea overlooks interpretations given by authors Gavan Daws and Ganath Obeyesekere that the priests had a large influence on the commoners' obedience to Cook, making sure they prostrated themselves before him. ${ }^{137}$ This in turn can be linked to the possibility that King Kalaniopuu wished to enlist Cook and the power of his firearms on his side. ${ }^{138}$ This is a much different possibility than the one Kaomea suggests by stating that:

As they had done throughout the islands of Polynesia, here in Hawaii, Cook and his men once again used their military might to assert their superiority over our native people. They taught our Hawaiian ancestors the proper way to treat foreign visitors, and we learned our lesson well. ${ }^{139}$

\footnotetext{
${ }^{136}$ Kaomea, 337.

${ }^{137}$ This may be argued in relation to Ganath Obeyesekere's argument that the Hawaiians were attempting to befriend Cook for their own motives in wars with neighboring islands.

${ }^{138}$ As suggested by Gavan Daws and Ganath Obeyesekere. Courting the British for their firepower was also true in other regions of the Pacific.

${ }^{139}$ Kaomea, 337.
} 
Furthermore, the Hawaiians continued to steal from Cook and his men, an act that may be out of character for those who are trying so hard to be "polite, hospitable, fearful of giving offense, eager to please, and sensible of their own inferiority." characteristic of theft is not a submissive position, but rather a dominant one. Last but not least, Kaomea forgets to recall that it was the Hawaiians who killed Cook, and no one ventured back to Hawaii for some seven odd years because of the reputation carried back on the Discovery and Resolution that the Hawaiians were aggressive beings.

Overall, Kaomea's argument contributes to unveiling the influence of the tourist industry in Hawaiian education, and the link that she makes to Cook and his men in propagating early attitudes of foreign interest in Hawaii is understandable. However, the evidence that Kaomea uses and the manner in which she uses it does not improve her case, especially in tying Cook into the modern tourist industry of today. Ultimately, Kaomea's article helps to show the influence of predominant social structures, such as the tourist industry, aimed at preserving their own self-interest; however, it does not explain how Cook's portrayal is manipulated by that influence. Instead she targets Cook as an instigator to the tourist industry's agenda of creating hospitable attitudes, all the while portending to strive for historical accuracy while overlooking a broader range of possibilities and circumstances that occurred well over two hundred years ago.

\section{Tourist Era Textbooks}

Let us return to the chronological analysis of Hawaiian textbooks beginning with Helen Bauer's Hawaii: The Aloha State, which has served fourth graders for almost fifty

\footnotetext{
${ }^{140} \mathrm{An}$ act I see as having dual purpose. One, to test the defense of the other. Two, the obvious advantage in acquiring the stolen possession.
} 
years. ${ }^{141}$ The text was written originally by Bauer in 1960, and then expanded and edited by Ann Rayson in the 1990's. As shown by Kaomea, Bauer's text reflected the tourist era attitude that began to grow during the 1960's - positively portraying Cook and his men. Other elements that deserve attention are Bauer's denigration of native Hawaiians, the upholding of Cook as Lono story, and the minimizing or omitting cases of sex, theft, and violence involved in the first contact between Cook and native Hawaiians.

More than simply casting Hawaiians into a hospitable subservient culture within the tour book format, Bauer's textbook also degrades native Hawaiians. For example, the most degrading comment that Bauer makes comes from the initial encounter between the British and Hawaiians. She explains that Cook "tied some brass medals and some nails to a rope and let them down to the canoes." She describes the "natives" being as "delighted as children with their new toys!" $" 142$ This statement is blatantly belittling to the Native Hawaiians, and distorts Cook's portrayal.

Bauer's upholding of the Cook as Lono story raises important issues to analyze.

She begins with the above quote describing the "temple of Lono" coming into Kealakekua Bay. Bauer then describes that the Hawaiians bowed down to Cook and stayed down until he told them to rise. Next, Bauer makes the claim that, "Cook probably did not realize that they thought he was a god, only that they were showing respect for him." ${ }^{143}$ As we have traced, this statement is a result of the work of Fornander and Alexander contesting Dibble's overly religious view. Further upholding the Cook as Lono story, Bauer reports that on Kona (Kealakekua Bay), Cook was led to the stone temple, or heiau. She uses quotes again stating that the Hawaiians remarked, "Since you

\footnotetext{
${ }^{141}$ Titled Hawaii: The Aloha State until 1997.

142 Bauer, Hawaii, the Aloha State (Honolulu: Bess Press, 1982), 50. Who Bauer is quoting is a mystery.

${ }^{143}$ Bauer, 51.
} 
are the god Lono, we will honor you as a living god." ${ }^{\text {144 }}$ Bauer uses this statement as part of her support to the Cook as Lono story; this story helps her to explain and justify the murder of Captain Cook.

Bauer describes the remainder of Cook's account within the Cook as Lono context. She explains that one night a native stole a boat from the Discovery and that Cook made a decision to take the King and hold him until the boat was returned. Bauer follows this by saying that, "An angry crowd gathered; some of the men with daggers, some with clubs." She continues by explaining that a "native" aimed a dagger at Cook, and he in return shot a blank out of his gun. This shot, she describes, only angered the crowd. She explains that Cook then fired a real shot, and Cook's men also began to fire. A Hawaiian then grabbed Cook, and as Cook escaped he fell and let out a groan. Bauer then reports the justifying exclamation, “"Ah he groans! The natives said. 'He is no god." " 145 She then describes that Cook was struck down and stabbed in the back with a dagger. Bauer uses the Cook as Lono story to legitimize Cook's death by explaining how the Hawaiians discovered his true identity; however this only destabilizes the story even more.

Bauer's description of the aftermath (i.e. the treatment of Cook's body) is noteworthy because it, as other accounts, convolutes the Cook as Lono story. She explains that after Cook's death the fighting continued, and that many "natives" were killed and a few sailors as well. Bauer then writes, "Finally there was peace." After announcing that a resolution had been made, she continues with the events of the aftermath. She reports that Cook's bones were divided among the priests and chiefs, but

\footnotetext{
${ }^{144}$ Bauer, 51.

${ }^{145}$ Bauer, 52.
} 
then that they were given back. She then adds that the bones were buried in Kealakekua Bay, where Cook's monument now stands. The curious part is that the Hawaiians came to a realization that Cook was not a god (because he groaned), yet the priests still treated his body in a ceremonial fashion. Why one may ask?

Omissions of violence, sexual relations, and theft are common in Bauer's text. Thus, the portrayal of events that led to Cook's death is inadequate. This is understandable at the fourth grade level, but an accurate historical account might still be maintained with softened tones.

Fortunately, not all the texts of this period mimic tour guidebooks. Shoal of Time, written by Gaven Daws in 1968, is one of the longest used historical texts on Hawaii. Although it is more a historical account than a contemporary textbook, it is still used today at the $9^{\text {th }}$ and $11^{\text {th }}$ grade levels and in college. Daws, originally from Australia, was the first person to graduate from the University of Hawaii with a Ph.D. in Pacific history. ${ }^{146}$ Daws's style has been critiqued for its sensationalism. Critics also note that he relies heavily on Euro-American accounts and develops a Eurocentric approach to his work - choosing to disregard some of the Hawaiian accounts. Daws elaborates frequently on sexual relations and the use of violence, but his most important contribution is his theory on the story of Cook as Lono. Given the controversial nature of his work, Shoal of Time has most likely remained in the Hawaiian school system curriculum over the past forty years as a comparative tool to analyze and critique. Overall, Daws's work represents a strongly western portrayal of Cook at a time when tourism was on the rise in Hawaii.

${ }^{146}$ Michael Tsai, “Gavan Daws,” http://the.honoluluadvertiser.com/150/sesq6daws 
Daws's Eurocentric tendency arises early in his work, establishing a lack of faith in Hawaiian accounts as a means to his discourse. He uses a prologue to quickly provide the early Polynesian background to his starting point, which is essentially Captain Cook's arrival. He explains that it was in the eighteenth century, at the end of the great age of exploration in the Pacific, that the Hawaiian Islands became known to Europeans. ${ }^{147}$ Credit is quickly given to Cook for the accomplishments of his prior voyages, and then an explanation is given on how Cook was commissioned for a third voyage to find the Northern Passage. This brief background suffices for Cook's sake, but not necessarily the Hawaiians. Because Daws begins his history at Cook's arrival, giving only a brief explanation of early long-distance travel by the Polynesians that spans back nearly a millennium, he opens himself up to be criticized for implementing a Eurocentric perspective. $^{148}$

Daws's Eurocentric approach does warrant merit and contributes to Cook's overall portrayal by limiting the use of Hawaiian accounts skewed and extracted during the missionary era. Even though chapter one is twenty-four pages long and is devoted entirely to Cook's time in and around Hawaii, and even though it has been argued that this may be excessive, especially in proportion to Hawaiian history dating back to the eighth century AD, Daws's aim toward historical accuracy is laudable. ${ }^{149}$ In addition, Daws provides a thorough account of the event, and I feel that historically it makes good sense to weigh heavily the importance of the Hawaiian - English encounter. It was undoubtedly a turning point in Hawaiian history. It may even be argued that Daws is

\footnotetext{
${ }^{147}$ Gavan Daws, Shoal of Time: A History of the Hawaiian Islands (New York: Macmillan, 1968), xi.

${ }^{148}$ Daws, xii. Daws sums up Polynesian dispersion in one paragraph, explaining that it was difficult to get agreeable information from members of the different islands in Hawaii.

${ }^{149}$ Charles H. Hunter, "Review of Books," review of Shoal of Time: A History of the Hawaiian Islands by Gavan Daws, The Pacific Historical Review 38, no. 2 (May 1969): 241. (JSTOR).
} 
correct in beginning his account here with such breadth, for written history is often regarded as academically acceptable, whereas oral history often has too many variables with too few accountable persons.

Daws has a strong propensity to elaborate on the sexual relations between Cook's men and the Hawaiians, wielding a Eurocentric perspective throughout. One of the areas Daws elucidates upon is the manner by which venereal disease spread. He explains that the orders and wishes of Captain Cook to maintain sexual abstinence fell victim to circumstance. Daws, as others before him, reveals that Cook, knowing that venereal disease was present among the ships, initially banned women from boarding. In addition, on Cook's first visit, he sent out small recognizance parties that had to be checked prior to departure, allowing only men showing no signs of disease to go ashore. ${ }^{150}$ This however was not enough to prevent an outbreak. Besides the obvious reason of willing seamen, Daws explains that the Hawaiian women did all in their power to allure men inside their houses, even drawing them in by force. A year later, after Cook and his men made another attempt at the Northern Passage, they returned to 'winter' at the islands. In the waters outside of Maui, they traded again with the natives, and in so doing noticed that the disease had already spread across the islands. According to Daws, once venereal disease was visible among the natives, they felt no reason to continue banning the freespirited women from coming onboard. ${ }^{151}$ Despite allegations made during the missionary era, Daws claims that Cook was "abstemious." ${ }^{152}$ He dismisses the claim by Kamakau that Cook also engaged in intercourse. This is done by weakening credit to oral accounts. In describing accounts that were told by Hawaiians shortly after Cook's death, Daws

\footnotetext{
${ }^{150}$ Daws, 6.

151 Daws, 9.

152 Daws, 6.
} 
writes that, "They even took the trouble in their stories to provide Cook with a native princess for a lover."153 Again, Daws's tone against Native Hawaiian accounts opens him up to criticism for his Eurocentric perspective.

In order to better understand the relationship between the Hawaiian's tendency to steal, the English's use of firearms, and the violence that often ensued, Daws provides a few helpful insights. The Hawaiians, as other Polynesians, are continuously noted for their theft, and Cook knew about this tendency. Daws explains that Cook and his men differed in their approach to handling the Hawaiians' tendency to steal. The Captain was stern on the idea that aggression with firearms should only be used as a last resort. On the other hand, his men believed that by using aggression upfront, it would prevent incidents by instilling fear. An example of this as it is often, but not always, noted is that Lieutenant Williamson shot and killed a native while searching for a watering hole. As mentioned in Fornander and Alexander, it may have been that he was provoked to a degree. ${ }^{154}$ It should be noted that Polynesians allegedly gained more respect for others once their ability to defend themselves was displayed. Defending oneself over tangible objects would be one way to test this. Thus, Williamson and others may have used good reasoning in their approach to using firearms against the Native Hawaiians. Also helpful is Daws's description of an earlier act of aggression when a native stole a cleaver from one of the ships. Williamson fired a shot, and then backed off. In response, the natives pelted the pinnace with stones. ${ }^{155}$ It is shortly after Williamson's firing episodes that Cook went ashore, and I would contest, as others have, that the fact the natives bowed down to him had something, albeit not everything, to do with these firings. However,

\footnotetext{
153 Daws, 24.

${ }^{154}$ Accounts on this event vary in their detail.

155 Daws, 3.
} 
Daws describes that gunfire surprised the natives more than it frightened them. Although contrasting, this point too seems only natural, as the Hawaiians had not fully learned the capacity of firearms. Nonetheless, the story of Cook as Lono has its roots in the use of firearms.

Daws creates an interpretation of the Cook as Lono story that is difficult to refute. In asking why the Hawaiians killed Captain Cook, he states that it was not so much that the "Hawaiians" did. Daws explains that it was the priests of Lono:

It was not the Hawaiians as a people who killed him, but the chiefs and their fighting men, devotees of $\mathrm{Ku}$, the war god, acting as protectors of their ruler, Kalaniopuu, against the incursions of a god that might very well not be a god, and whose period of ascendancy was in any case drawing to an end. Cook died in a distorted realization of the symbolic conflict that marked the close of the makahiki season. ${ }^{156}$

This clarifies why Cook was also worshipped so devotedly. Daws describes that it was through the priests' orders that the Hawaiian commoners prostrated themselves in front of Cook. It was the priests' fear that Cook and his men would bring harm to King Kalaniopuu. This was perhaps becoming the picture that filled their heads, as Cook and his marines marched Kalamiopuu to the beach. Unfortunately, another chief, the one who unwarrantedly entered the bay, was shot and killed; this along with the botched attempt to kidnap the King simultaneously fueled a picture of paranoia for the priests. Thus, writing from a Eurocentric point of view, Daws transfers the responsibility of Cook's death back on to the side of the Hawaiians through Kalaniopuu's priests.

Daws's goal of reestablishing a positive portrayal of Cook was beneficial to a time when western cultures began flocking to Hawaii for leisure. Reconstructing

\footnotetext{
${ }^{156}$ Daws, 27.
} 
Cook's image from its roots, Daws exposed the condemning influence of the missionary era. He asserts that Hawaiian accounts often exaggerated detail where the missionaries, concerned with blaming Cook's death upon his blasphemy in allowing himself to be worshipped, left it behind. ${ }^{157}$ Daws explains that this "bitterness" soon dissipated with the coming of the sesquicentennial celebration in 1928. He describes that Cook's achievements as an explorer were finally recognized in Hawaii as they had previously been in other parts of the world. This position makes good sense from the perspective of a native Australian, whose people often praise Cook for such accomplishments.

\section{Native Hawaiian Movement Era and Textbooks Today}

Hawaiians began resisting foreign interference beginning with the arrival of Captain Cook. Nearly two centuries later Hawaii had changed so dramatically that Native Hawaiians began to demand that their voice be heard in many arenas, including education. Native Hawaiian movement views worked their way into textbooks during the late twentieth century. Unfortunately, many of the changes that were made in response to the Native Hawaiian movements did little to change the accuracy of historical accounts.

Hawaiian students learn about Captain Cook in courses taught about foreigners and missionaries at the seventh grade level. A dominant text in the Hawaiian social studies program at this level is Hawaii: Our Island State (1979) written by Hawaiian residents Norris W. Potter, Lawrence M. Kasdon, and Dorothy Hazama. Hawaii: Our Island State provides a different portrayal of Cook in some respects. First, the Hawaiian perspective is elevated while the British perspective is diminished. Second, the authors

${ }^{157}$ Daws, 24. 
uphold the Cook as Lono story; however, they provide alternative information to this position, and create one of the first texts to report a doubt in it. Third, accounts of violence and sexual relations are minimized or deleted, and when violence is reported more emphasis is placed on the shortage of food supplies (a cause of the British) rather than the theft of iron (a cause of the Hawaiians).

The authors uplift the Hawaiian perspective in a variety of ways. For example, they explain that a "thriving trade developed," with the Hawaiians providing "60 pigs, yams, etc. for nails and some pieces of iron." Without an explanation of how much the Hawaiians valued iron, the tone in this passage seems to suggest that the Hawaiians were oversupplying the British, while Cook and his men gave only a few scraps of iron in return. Another example of this skewed perspective is provided in the authors' description of the aftermath of Cook's death, out of the blue they write, "The Hawaiians showed great courage against the superior weapons of the English."158 This Hawaiian patriotism is a clear example of the Native Hawaiian movement's influence upon the textbook.

Despite favoritism to the Hawaiian perspective, Captain Cook is portrayed with openness and fairness. The text begins its timeline of Hawaiian history on Cook's arrival. Chapter one, "Western Arrival: Captain Cook (1775-1795)" begins by clarifying that Cook may not have been the first European to visit Hawaii. The authors suggest that Spanish explorer Juan Gaetano may have visited the islands in the mid 1500's. Most scholars agree that this speculation is no longer valid, nevertheless more possibilities add

\footnotetext{
${ }^{158}$ Norris W. Potter, Lawrence M. Kasdon and Dorothy Hazama, Hawaii: Our Island State (Honolulu: Bess Press, 1979), 3.
} 
to the creative process of education. ${ }^{159} \mathrm{Next}$, a brief background is given explaining Cook's other voyages, but not why he was making them. Cook is also credited for his remarkable seamanship. The story of Lono then ensues. The authors explain that the symbol of Lono, a tapa, and the sails on the ships were similar and the legend promised that when Lono returned he would arrive with food. ${ }^{160}$ The authors write that the Hawaiians treated him as a chief of the highest rank or as a god, and that they may have thought he was the god Lono returned. This ambiguity over Cook's perceived status is not uncommon today, and ultimately it allows for scholastic change; nonetheless, it is the first textbook in this analysis that entertains the possibility that there is doubt in the Cook as Lono story. Despite this breakthrough however, the text continues by subscribing more wholeheartedly to the Cook as Lono story.

As the authors continue with the Cook as Lono story, they provide two juxtaposing points that lead to the topic of violence. Shortly after leaving Kealakekua Bay, a storm damaged one of the ships and the English were forced to return. The authors explain that upon their return to Kealakekua Bay it was now the season of $\mathrm{Ku}$, a war god, and that they were not welcomed as before. This description fits into the Cook as Lono mold, however it creates contradictions with other explanations that are given. For example, added to the seasonal shift description is the statement that supplying food for the crew left the Hawaiians with barely enough food for themselves. This burden angered

\footnotetext{
${ }^{159}$ Grove A. Day, review of Hawaii: A Century of Economic Change, 1778-1876, by Theodore Morgan, The Pacific Historical Review 18. no. 2 (May 1949): 273. (JSTOR); Klaus Mehnert, "Review: The Discovery of Hawaii," review of Hawaii's Discovery by the Spaniards: Theories Traced and Refuted by John F. G. Stokes, Geographical Review 30, no. 3 (July 1940): 511. (JSTOR); Beaglehole, The Life of Captain James Cook, 110; Erik W. Dahlgren, The Discovery of the Hawaiian Islands (New York: AMS Press, 1977).

${ }^{160}$ Potter, Kasdon, and Hazama, 3. The element of Cook and his men bringing food does not get mentioned too far beyond this. I would ask how much food did Cook and his men actually bring for the Hawaiians? Aside from a few animals, probably not much, and therefore it has the potential for tarnishing the Lono image slightly.
} 
the Hawaiians, and even more so as the British returned less than a day after their departure. So, was it because the season changed or was it because food supplies were being depleted that aggression began? The Cook as Lono story certainly has no bearing on the latter, and thereby creates an alternative reason to explain the events that culminated in the tragedy of Cook's death.

The authors' position on violence is important to address in other cases as well. The authors state that no serious quarrels between the English and Hawaiians took place, and that nothing suggested the tragic events that were to follow. ${ }^{161}$ However, according to the majority of other accounts, several conflicting events had taken place prior to the events leading to the battle that took Cook's life. For example, Lieutenant Williams allegedly provoked the firing upon and killing of a Hawaiian as he searched for a watering hole at Kauai. Other examples, such as those concerning the Hawaiians' tendency to steal are lacking as well - instead more focus is placed upon the British burdening food supplies. In addition, the authors do describe that Hawaiians quarreled with Cook's crew prior to Cook's death, and that some Hawaiians threw rocks and then stole a boat off one of the ships. Subsequently, when Cook attempted to take the king (which king is not given) aboard and hold him hostage, fighting broke out and Cook was killed. However, one important part that is lacking is that once Cook had King Kalaniopuu on the beach another chief attempted to enter the bay, which had been blockaded earlier by the British. This chief was shot and killed. Word of this quickly spread exciting the masses. This event undoubtedly escalated matters toward Cook's death. In addition, no account of the sexual transactions that occurred between the British

\footnotetext{
${ }^{161}$ Potter, Kasdon, and Hazama, 5.
} 
and Hawaiians is reported; perhaps the grade level regulates the amount of sex and violence that can be mentioned.

Overall, the authors create a balanced work, one with strengths and weaknesses. Their account lacks explanations about fraternization and inter-island warfare, and it omits sexual transactions that were part of trade and spread diseases that became responsible for the death of many Hawaiians. They, as most other authors, also convolute the Cook as Lono story with their description of the Hawaiians' treatment of Cook's body after his death. However, Hawaii: Our Island State is a classic example of the progressive nature of textbooks. The authors uplift the Hawaiian perspective, challenging an entirely Eurocentric view while at the same time treating Cook openly and fairly. And most importantly, the authors provide a progressive move toward historical balance by suggesting that other reasons aside from the Hawaiians' alleged belief in Cook as Lono, created aggressions between the two cultures.

Potter, Kasdon, and Hazama originally wrote History of the Hawaiian Kingdom as Hawaii: Our Island State in 1979. In 1983, Ann Rayson changed the title and added herself to the list of authors. Most of the book has remained the same, especially the part pertaining to Captain Cook. However, Rayson's edition again adds more to the Hawaiian perspective. The title change itself is indicative of the native Hawaiian agenda. The majority of change is found in new pictures and artwork. The new artwork is by Herb Kawainu Kane, a Hawaiian resident, and strongly elevated a Hawaiian tone throughout the textbook.

In 1997, Helen Bauer's Hawaii: The Aloha State was revised into Hawaii: The Pacific State. Again Ann Rayson is added as an author, and again the title change reflects 
the work of the native Hawaiian movement. ${ }^{162}$ It is important to note that the majority of the text has not changed in its nearly fifty years at print, and therefore I consider Bauer's textbook the work that is actually still used. In regards to the portion dedicated to Captain Cook, most of the change in text is subtle. The majority of change brings the native Hawaiian voice to the forefront by de-emphasizing the importance once placed on Cook. These changes reflect the work of the Native Hawaiian movement; however as Kaomea argued earlier, the subtle changes do nothing to change the tour book like format.

A clear example of Rayson's shift in perspective follows: Bauer writes in summarizing the story, that, "The Hawaiians had learned the way of the white visitors and especially the use of iron. The visitors had found an island paradise." Rayson adds a twist to the latter statement. She writes, "The visitors had found a new [my italics] island paradise to colonize and use." Although most of the other changes are subtle, this final statement is a clear message of the Native Hawaiian voice.

By the time Hawaiian students reach high school the lesson of Captain Cook is perhaps redundant. However, his story is still taught at the ninth, and or, eleventh grade level as part of the study of Hawaiians' economic history. One of the most recent publications, A History of Hawaii (1993), comes from the University of Hawaii at Manao and is authored by professors Linda K. Menton and Eileen H. Tamura. The publication is a project of the Curriculum Research and Development Group (CRDG), a research unit that works in tandem with the department of education at the University of Hawaii at Manao. The text is formatted with specific goals and set to meet "content and

\footnotetext{
${ }^{162}$ As discussed by Julie Koamea, Aloha is an often misunderstood and misused Hawaiian word.
} 
performance standards," according to the CDRG curriculum. ${ }^{163}$ Yet, despite whatever goals may have been set by the CDRG, Menton and Tamura's textbook contributions in regards to the subject of Captain Cook are scarce.

The authors encapsulate their theme of Hawaiian economics with the Cook as Lono story. Captain Cook is introduced in chapter two, "Hawaii's Economic History to 1900." As noted by the authors, Cook's landing was a watershed event for the Hawaiian economic system, changing their subsistence way of life forever. Following an introduction to both the subsistence and market economies, the authors simultaneously uphold, question, and convolute the Cook as Lono story. Trade is briefly described as the authors maintain the Cook as Lono story and create a pro-Hawaiian position in their account. The description of Cook's death and the events leading up to it are minimal. Initiating their discourse on Captain Cook, the authors outline the clash between the Hawaiians' subsistence economy and the British market economy. The chapter begins with a description of Hawaii's early subsistence economy, and then introduces the market economy's style and method of operation as comparative material. A chart is then provided designed to clearly delineate the two economy types through an activity of filling out a chart, and then questions are provided such as, "What happened when these two economic systems met?"164 Then the textbook fails to answer this question and goes on to mention "Lono Arrives." The reader is left confused and uninformed.

\footnotetext{
${ }^{163}$ Curriculum Research and Development Group, "Alignment of A HISTORY OF HAWAI'I, CHINA: UNDERSTANDING ITS PAST, THE RISE OF MODERN JAPAN (in progress) with the Content Standards - HCPS II," University of Hawaii at Manoa. http://www.hawaii.edu/crdg/sections/ss/documents/SocStud_alignment.pdf (accessed January, 11, 2009). ${ }^{164}$ Linda K. Menton and Eileen H. Tamura, A History of Hawaii (Honolulu: University of Manoa, 1999), 36.
} 
Menton and Tamura uphold, question, and convolute the Cook as Lono story. Directly after explaining the two separate types of economies, the authors curiously provide a fictional Hawaiian account about Cook. ${ }^{165}$ The fictional account relates various links between Captain Cook and the Hawaiian god Lono, such as the sails of the ships and their similarity to the symbol of Lono. However, aside from the mention of iron, it is not clear how this fictional passage relates to the overall economic theme of the chapter. Even more baffling, the authors follow by retracting, stating that recent studies suggest that perhaps the Hawaiians were too practical to mistake Cook (a foreigner who did not look, speak, or act like a Hawaiian god) for Lono. The authors then ask, "What do you think?" Oddly enough the account proceeds with the Cook as Lono story, almost as if no retraction had occurred. It describes that Cook and his men visited during the Makahiki season, and that "With great joy the Hawaiians welcomed Cook as their returning god, Lono." ${ }^{166}$ After reestablishing the idea that Cook was Lono, the authors return to the theme of trade.

The authors' account of trade is brief and takes a pro-Hawaiian position. Trade at both Kauai, and a year later at Hawaii are described. Menton and Tamura explain that the Hawaiians offered Cook many gifts, and in return the Englishmen gave them pieces of iron. Although it is true that the Hawaiians supplied the ships with an abundance of food, and that the British bartered with pieces iron, Menton and Tamura mention nothing about the Hawaiians tendency to steal and the value they placed on iron. In addition, the authors also do not include other items that the English traded such as plants, animals, clothing, and tools. These oversights create a pro-Hawaiian position, which the authors perpetuate

\footnotetext{
${ }^{165}$ Menton and Tamura, 36.

${ }^{166}$ Menton and Tamura, 37.
} 
as they provide a short description of Cook's visit at Kealakekua Bay. Foreshadowing Cook's death, they state that this time, "instead of nails, they gave daggers..."167

Cook's final days are reported, weaving in the Cook as Lono story, minimizing explanation of theft and violence, and suggesting that he died by the implement he introduced (the dagger). The authors describe that Cook and his men left again to return north, but a winter storm caused them to return. The authors exclaim with enquiry, “Imagine the Hawaiians' surprise at Lono's quick return. Hadn't they just visited for the Makahiki? And what was this? A god with a broken ship? Doubts of Cook's divinity must have arisen." In describing the events that occurred surrounding Cook's death the authors simply write:

Problems arose between the Hawaiians and Cook's men. During the fray that followed some of the men on both sides were killed, including Captain Cook, who was struck down with a club and stabbed in the back with a dagger. ${ }^{168}$

Even though this chapter is intended to focus on economics, the brevity of Cook's death and the events that surrounded it are curious, especially after dedicating so much space to a fictional account and the Cook as Lono story. One wonders if this story continues to be told simply because it has been in the past.

Overall, crucial details are left out of Menton and Tamura's account. Their economic theme is weakly supported, and their decision to uphold the Cook as Lono story appears faulty. Not once do the authors mention anything about stealing. Both encounters are portrayed as peaceful barter extravaganzas, minus the 'fray' leading to Cook's death, and the value the Hawaiians placed on iron is not described. In addition,

\footnotetext{
${ }^{167}$ Menton and Tamura, 37. A tone that the English gave the weapon of Cook's demise may be read in to this, especially without any clarification on the authors' part. This however may not have been the case, because the Hawaiians allegedly had daggers prior to Cook's arrival.

${ }^{168}$ Menton and Tamura, 38.
} 
sexual transactions, another part of the encounter's trade, are also omitted. Furthermore, violence that occurred from both sides is extremely reduced. These reductions and omissions reflect the Hawaiian movement's efforts to better portray the Hawaiians. The authors' section on Captain Cook is only three pages long, and much of it is spent on the Lono story. Interestingly, doubt in the Lono story is introduced and then ignored, further convoluting the portrayal of Cook as Lono. Describing the systematic change in the Hawaiians' economy, which is rather obvious, is the only major contribution of the authors. 


\section{Summary and Conclusion}

Captain James Cook's portrayal has changed over time. In particular, the way Cook has been portrayed over the past two centuries in accounts of Hawaiian history has been adjusted - and often - distorted to reflect the prevailing interest of different authors in different eras. Distortions of Cook's portrayal began with editor Dr. John Hawkesworth's publication of Cook's first journey. By the request of Cook, the editor of his second world voyage, John Douglas, provided a clearer account. Following Cook's death, eulogies and artwork elevated him to a position of divine martyrdom, a symbol of the Enlightenment. Biographers then began to portray Cook as a national hero who was acclaimed by the people of the struggling British Empire.

These praises were soon replaced by condemnation of Cook in accounts of Hawaii written during the "missionary period" of Hawaiian history. American missionary Sheldon Dibble and Hawaiian missionary students David Malo and S.M. Kamakua condemned Cook for allowing himself to be worshipped as a god. However, this condemnation did not last.

Shortly after, during the "plantation era" there was an expanding governmental system in Hawaii and more emphasis on economic advancement. Abraham Fornander and William Alexander wrote accounts of Hawaiian history that allowed for greater change and a movement away from sectarian education. By the late $19^{\text {th }}$ century, these "plantation era" accounts still reflected inaccuracies from the faulty foundation of the "missionary era" works, but they were changing.

The turn of the $20^{\text {th }}$ century brought the work of Ralph Kuykendall, who was commissioned by the Hawaiian government to write a textbook on Hawaiian history that 
would reflect the growing strength of "Americanization” in Hawaii. ${ }^{169}$ Kuykendall emphasized capitalism and democracy and the value of American protection of Hawaiian interests. His portrayal of Cook stressed the successful trade between the native Hawaiians and Cook's voyagers; it downplayed the violence and sexual encounters that resulted from the trade in a way that reinforced the concept of the European and American intruders as protectors of Hawaii.

Kuykendall's pro-Americanization work remained the leading historical text for Hawaii for over thirty years. The Japanese attack on Pearl Harbor and World War II strengthened the message of the value of Hawaii being an American protectorate and the successful transition of Hawaii to statehood in 1959. Thus, Hawaiians became Americans.

During the 1960's tourism grew rapidly in Hawaii. As Julie Kaomea has argued, the Hawaiian social studies textbooks, beginning in the 1960's, show a striking similarity to tourist guidebooks. This uncanny parallel reflects the bias that authors created textbooks with during the "tourist era" in Hawaii. In addition, these authors continued to omit violence and sexual relations that resulted from trade between Cook's men and the Hawaiians. These omissions, as well as others, helped to create a favorable image between tourists and Hawaiians. Thus, adding strength to the "tourist era" mentality.

Native Hawaiian movements, beginning in the late 1960's and early 1970's propelled change in social studies textbooks, but it came slowly. It took nearly thirty years before major changes occurred, and even those changes were simply the repackaging of old goods. For example, the conversion of Helen Bauer's Hawaii: The Aloha State to Bauer and Ann Rayson's Hawaii: The Pacific State was made with only a

\footnotetext{
${ }^{169}$ Annexed in 1898, Hawaii and its government fell under the influence of American government.
} 
few changes; and those changes appear to be designed as merely "politically correct" efforts to assert a more native Hawaiian point of view. For instance, in order to bolster up the Hawaiian image, accounts of their tendency to steal is often reduced or omitted. Another example is the conversion of Hawaii: Our Island State into History of the Hawaiian Kingdom; the text remains the same, but beautiful new pictures adorn the pages, pictures by and orientated to a Hawaiian. Unfortunately, these changes only convolute the portrayal of Cook even further.

Historical accounts of Captain Cook in Hawaii were consistently geared to the time and interests they served. Historical accuracy was often lost in these accounts, and even today with such examples as History of Hawaii by Linda Menton and Hawaii: The Pacific State by Helen Bauer and Ann Rayson, historical accuracy has been sacrificed to some degree by the need to meet specific curriculum requirements mandated by the Hawaiian Department of Education. And although these texts meet the requirements set by the Department of Education or Curriculum Development and Research Group, they add little to correcting the portrayal of Cook.

Over two hundred years has passed since Cook's time in Hawaii, and yet still textbooks continue to change. What will the future textbooks reveal about Cook's time in Hawaii? Will they redevelop Cook's part in history as scholars aim to correct the accounts of his life and death, perhaps even restructuring the manner by which Cook was worshipped as Lono? Will they add information that better describes the inter-island warfare that Cook and his men sailed into, and perhaps something about Kamehameha's link to this event? Will they provide more trivial facts such as the amount of iron traded, 
or that Captain Cook could not swim? One hopes that future textbooks will give a richer, more accurate portrayal of Cook in Hawaiian history. 


\section{BIBLIOGRAPHY}

Alexander, William DeWitt. A Brief History of the Hawaiian People. New York: American Book Company, 1891.

Beaglehole, John Cawte. The Life of Captain James Cook. Stanford: Stanford University Press, 1974.

The Journals of Captain James Cook. New York: Penguin Books, 1999.

. Beaglehole, John Cawte. "Some Problems of Cook's Biographer." Mariner's Mirror 55, no. 4 (1969): 365 - 381.

Bell, Roger J. Last Among Equals: Hawaiian Statehood and American Politics. Honolulu: University of Hawaii Press, 1984.

Barrow, Terence. Captain Cook in Hawaii. Honolulu: Island Heritage Limited, 1976.

Bauer, Helen. Hawaii, the Aloha State. Honolulu: Bess Press, 1982.

Curriculum Research and Development Group. "Alignment of A HISTORY OF HAWAI'I, CHINA: UNDERSTANDING ITS PAST, THE RISE OF MODERN JAPAN (in progress) with the Content Standards - HCPS II." University of Hawaii at Manoa.

http://www.hawaii.edu/crdg/sections/ss/documents/SocStud_alignment.pdf (accessed January, 11, 2009).

Dahlgren, Erik Wilhelm. The Discovery of the Hawaiian Islands. New York: AMS Press, 1977.

Daws, Gavan. Shoal of Time: A History of the Hawaiian Islands. New York: Macmillan, 1968.

Day, Arthur Grove. Hawaii and Its People. New York: Meredith Press, 1968. 
Review of Hawaii: A Century of Economic Change, 1778-1876, by

Theodore Morgan. The Pacific Historical Review 18, no. 2 (May 1949): 272 274.

Dening, Greg. "Reviews of Books." Review of Captain James Cook by Richard Hough, The Apotheosis of Captain Cook: European Mythmaking in the Pacific by Gananath Obeyesekere, How "Natives" Think: About Captain Cook, For Example by David Sahlins, The William and Mary Quarterly 54, no. 1 (January 1997): 253 - 259. (JSTOR).

Dibble, Sheldon. History of the Sandwich Islands. Lahainaluna, HI: Press of the Mission Seminary, 1843.

Dotts, Sikkema and Mildred Sikkema. Challenging the Status Quo: Public Education in Hawaii, 1840-1980. Honolulu: Hawaii Education Association, 1994.

Edwards, Philip. The Story of the Voyage: Sea Narratives in Eighteenth-Century England. Cambridge: Cambridge University Press, 2004.

Fisher, Robin and Hugh Johnston. Captain James Cook and His Times. Seattle: University of Washington Press, 1979.

Fornander, Abraham. An Account of the Polynesian Race: its origin and migrations, and the ancient history of the Hawaiian people to the times of Kamehameha. Honolulu: Bishop Museum Press, 1909.

Hawaii Department of Education. "Hawaii Content and Performance Standards III Database." http://standardstoolkit.k12.hi.us/index.html (accessed November 20, 2008).

Hawkesworth, John. An Account of a Voyage Round the World with a Full Account of the Voyage of the Endeavor in the Year MDCCLXX Along the East Coast of Australia. Brisbane: Smith \&Paterson, 1969.

Howse, Derek. Background to Discovery: Pacific Exploration from Dampier to Cook. Berkeley: University of California Press, 1990. 
Hunter, Charles H. "Reviewed Works," review of Shoal of Time: A History of the Hawaiian Islands, by Gavan Daws. The Pacific Historical Review 38, no. 2 (May 1969): 241 - 242. (JSTOR).

Kamakua, Samuel Manaiakalani. Ruling Chiefs. Honolulu: Kamehameha Schools Press, 1961.

Kaomea, Julie. "A curriculum of Aloha? Colonialism and Tourism in Hawai'i's Elementary Textbooks." Curriculum Inquiry 30, no. 3 (Autumn 2000): 319 - 344. (JSTOR).

Kelly, Marion. "Some Thoughts on Education in Traditional Hawaiian Society." In To Teach the Children: Historical Aspects of Education in Hawaii. A Publication Accompanying the Exhibition Commemorating the 50th Anniversary of the College of Education and the 75th Anniversary of the University of Hawaii, 4 15. Honolulu: Bernice Paul Bishop Museum, 1982.

Kippis, Andrew. The Life of Captain James Cook. London: Printed for G. Nicol and G.G. $\mathrm{J}$ and $\mathrm{J}$ Robinson, 1788.

Kuykendall,_Ralph S._A History of Hawaii. New York: McMillan Company, 1933.

Kuykendall, Ralph S., and A. G. Day. Hawaii: A History from Polynesian Kingdom to American Statehood. New York: Prentice Hall, 1948.

Lahaina Restoration Foundation. "Hale Pa'i." http://www.lahainarestoration.org/halepai.html (accessed December 7, 2008).

Lloyd, Christopher. The Voyages of Captain James Cook: Round the World. London: The Cresset Press, 1949.

Malo, David. Hawaiian Antiquities (Moololo Hawaii). Honolulu: Bernice P. Bishop Museum, 1951. 
Mehnert, Klaus. "Review: The Discovery of Hawaii." Review of Hawaii's Discovery by the Spaniards: Theories Traced and Refuted, by John F. G. Stokes. Geographical Review 30, no. 3 (July 1940). (JSTOR).

Menton, Linda K., and Eileen H. Tamura A History of Hawaii. Honolulu University of Hawaii 1999.

Obeyesekere, Gananath. The Apotheosis of Captain Cook: European Mythmaking in the Pacific. Princeton: Princeton University Press, 1997.

Pearson, W. H. "Hawkesworth's Alterations." The Journal of Pacific History 7, (1972): 45 - 72. (JSTOR).

Potter, Norris W., Lawrence M. Kasdon and Dorothy Hazama. Hawaii: Our Island State. Honolulu: Bess Press, 1979.

Potter, Norris W., Lawrence M. Kasdon, and Ann Rayson. History of the Hawaiian Kingdom. Honolulu: Bess Press, 2003.

Rayson, Ann and Helen Bauer. Hawaii: The Pacific State. Honolulu: Bess Press, 1997.

Sahlins, Marshall David. How “Natives” Think: About Captain Cook, For Example. Chicago: University of Chicago Press, 1995.

Smith, Bernard. "Cook's Posthumous Reputation," in Captain James Cook and His Times. Edited by Robin Fisher and Hugh Johnston. Seattle: University of Washington Press, 1979.

European Vision and the South Pacific. New Haven: Yale University Press, 1985.

Stokes, John F. G. "Origin of the Condemnation of Captain Cook in Hawaii," in the $39^{\text {th }}$ Report of the Hawaiian Historical Society For the Year 1930 with Papers Read at the Annual Meeting. February, 10, 1931. 
Sutter, Valerie. "Book Reviews." Review of Challenging the Status Quo: Public Education in Hawaii, 1840-1980, by Cecil K. Dotts and Mildred Sikkema. History of Education Quarterly 35, no. 3 (Autumn 1995): 305 - 306. (JSTOR).

Tsai, Michael. "Gavan Daws.” The Honolulu Adviser July 2, 2006. http://the.honoluluadvertiser.com/150/sesq6daws (accessed March 15, 2009).

Williams, Glyndwr. The Death of Captain Cook: A Hero Made and Unmade. Cambridge: Harvard University Press, 2008. 